\title{
LA SAGRADA ESCRITURA SEGÚN SAN JUAN DE ÁVILA
}

José Manuel Sánchez Caro ${ }^{1}$

DOI: https://doi.org/10.52039/seminarios.v57i201-202.331

INTRODUCCIÓN

No son muchos los estudios sobre la importancia de la Sagrada Escritura en la obra escrita de san Juan de Ávila. La mayoría de los trabajos se han concentrado en su tarea pastoral, especialmente en su predicación, así como en su aportación a Trento, sus orientaciones para la vida espiritual $\mathrm{y}$, no en último lugar, su riquísima doctrina sobre el sacerdocio ministerial. De entre la extensa bibliografía sobre el tema, publicada en el volumen I de sus obras completas el año 2000, apenas si pueden rescatarse diez títulos. Sobresalen los estudios de Tarsicio Herrero del Collado, de Juan Leal y los breves apuntes de Mons. Laureano Castán Lacoma, todos ellos sin embargo anteriores al concilio Vaticano II y a las últimas ediciones críticas de las obras del Maestro Ávila². Otros han incidido en el paulinismo del gran predicador andaluz ${ }^{3}$ o en aspectos más concretos $^{4}$, sin olvidar la síntesis del útil diccionario dedicado a su persona y su obra, así como la introducción a la edición de los «comentarios bíblicos» del santo ${ }^{5}$. A estos trabajos ya reseñados, ha de añadirse la buena presentación sintética de Julio Alonso Ampuero, el estudio más reciente que conozco6.

1. Doctor en Sagrada Escritura. Ha sido rector de la Universidad Pontifica de Salamanca, así como de la Universidad Católica de Ávila.

2. J. LEAL, «El estudio de las Sagrada Escritura en el Beato Juan de Ávila», Maestro Ávila 1 (1946) 31-7; L. CASTÁN LACOMA, «Un gran conocedor de la Sagrada Escritura, el Beato Maestro Ávila», Cultura Bíblica 60-63 (1949) 164-68; 232-5; T. Herrero del Collado, Pastoral Bíblica del Maestro Juan de Ávila, Granada 1961.

3. R. García-VillosladA, «El paulinismo de Juan de Ávila», Gregorianum 51 (1970) 61547; A. HuergA, «El Beato Ávila, imitador de San Pablo», Vida Espiritual 9 (1965) 247-91.

4. F. CERECEDA, «Dos proyectos del 'Instituto Bíblico' en España durante el siglo XVI», Razón y Fe 133 (1946) 275-90; I. GomÁ CIVIT, «Un texto inédito del Beato Maestro Juan de Ávila sobre el estudio de la Sagrada Escritura», Estudios Bíblicos 1 (1943) 107-119; F. MARTín, Cristianismo y erasmismo español: Juan de Valdés, S. Juan de Ávila y el «Quijote» de Cervantes. Lección inaugural del curso académico 1977-78, Salamanca, Universidad Pontificia de Salamanca 1977; ID., San Juan de Ávila, ¿erasmista?, Centro de Estudios Ibéricos y Americanos de Salamanca, Salamanca 1998.

5. J. Esquerda Bifet, Diccionario San Juan de Ávila, Burgos, Monte Carmelo 1999; San Juan de Ávila, Obras completas. Nueva edición crítica II. Introducciones y notas de L. SALA Balust - F. Martín HeRnÁndez, Madrid, BAC 2001, 5-21.

6. J. Alonso Ampuero, San Juan de Ávila y la Sagrada Escritura. Discurso de apertura del curso 2000-2001. Toledo, Estudio Teológico San Ildefonso, Seminario Conciliar 2000. 
A la luz de estos trabajos, surge la cuestión acerca de la necesidad de revisar el tema de la comprensión de la Sagrada Escritura en los escritos de san Juan de Ávila. En mi opinión, los trabajos sobre el conocimiento que de la Escritura tenía el gran predicador, su pensamiento acerca de la naturaleza de ella, así como el análisis de sus métodos de interpretación, necesitan aún de alguna reflexión y no poco trabajo. Ante la imposibilidad de someter ahora a análisis toda la obra de escritor tan abundante, me ha parecido oportuno centrarme en su obra principal, el Audi filia, y esto por las siguientes razones. En primer lugar, porque, aunque la edición definitiva de 1574 hubo de ser arreglada por sus discípulos, cuando ya no vivía el Maestro, sin embargo es claro que nos ofrece su pensamiento último en el punto que nos interesa, la concepción y el uso de la Sagrada Escritura, particularmente sensible tras haber incluido el índice de Fernando de Valdés (1559) la edición de esta obra, hecha en 1556, sin su permiso. No olvidemos, además, la tajante prohibición de tener acceso directo a la Biblia en lengua vulgar, así como la práctica eliminación de acceso directo a cualquier edición de la Biblia por parte de los laicos. Interesa también, porque san Juan de Ávila presta una especial atención a sus afirmaciones sobre la Sagrada Escritura, a la vista de cuanto se había dicho en el concilio de Trento, concluido en 1562, en abierto rechazo de las doctrinas de Lutero. Este hecho, precisamente, nos permite observar la orientación del Maestro Ávila antes de Trento y las correcciones básicas, que él incluye en atención a la nueva situación provocada por el índice de Valdés, por las doctrinas protestantes y por las decisiones de Trento. Finalmente, a los ojos de un escriturista, ambas ediciones de esta bella obra espiritual ofrecen una gran riqueza de observaciones sobre la Sagrada Escritura, que merecen resaltarse, algunas por primera vez, otras como confirmación de estudios ya existentes $^{7}$. Junto al Audi filia, su obra más importante, tendré en cuenta también las pláticas espirituales, el breve e incompleto tratado sobre el sacerdocio y los dos memoriales al Concilio de Trento. Este conjunto permite, a mi juicio, obtener una imagen básicamente fiel del pensamiento de nuestro autor sobre la sagrada Escritura. Debe tenerse en cuenta, sin embargo, que dejo aparte para mejor ocasión los sermones, los «comentarios bíblicos» y el inmenso tesoro de sus cartas. Estos son los límites y las limitaciones del presente estudio.

En consecuencia, lo que se intenta en este trabajo de manera sintética es presentar la consideración que sobre la naturaleza de la Sagrada Escritura tiene san Juan de Ávila, así como describir cuáles son los principios hermenéuticos que emergen en su lectura e interpretación de la Sagrada Escritura, y qué piensa acerca de la lectura de la Biblia y de cómo ha de ser usada para alimentar la

7. Sobre el origen, destinataria y vicisitudes del Audi filia, escrita para doña Sancha Carrillo, me atengo a la completa introducción de sus últimos editores, SAN JUAN DE ÁvILA, Obras completas. Nueva edición crítica I, Introducciones, edición y notas de L. SALA BALUST - F. MARTíN HERNÁNDEZ, Madrid, BAC 2000, 169-193. 


\section{La Sagrada Escritura según San Juan de Ávila}

vida espiritual del cristiano. Además, no es de menor interés poner de relieve su reflexión sobre la relación entre la Biblia y la Iglesia, cuestión tan actual en este momento, después de la publicación de la exhortación postsinodal de Benedicto XVI, Verbum Domini ${ }^{8}$. De este modo, sin que el santo lo formulase en la mayoría de los casos de manera explícita, pueden sin embargo rastrearse en esta obra con sus dos ediciones y en las otras ya indicadas, los elementos básicos de lo que podríamos llamar una teología de la Sagrada Escritura en el siglo XVI. Lo cual, sin duda, tiene siempre interés.

\section{LA PALABRA DE DIOS}

Como era de esperar, no hay un tratamiento teórico acerca de la palabra de Dios en el Audi filia de san Juan de Ávila. Tampoco lo encontramos en ninguna otra obra suya. Sin embargo, a poco que fijemos nuestra atención, encontramos una serie de elementos dispersos, que, organizados de manera conjunta, sí nos dan una visión relativamente completa acerca de lo que el santo Maestro piensa sobre esta importante cuestión. En cuatro breves apartados podemos organizar su doctrina.

En primer lugar, para él es claro que Dios habla en la Sagrada Escritura. La palabra de Dios está dicha toda en la Sagrada Escritura y la razón humana debe inclinarse ante ella. En efecto, en su explicación del pasaje et inclina aurem tuam, recomienda el santo que nos pongamos a la escucha humilde de Dios, sin querer investigar más de lo que nuestra capacidad puede comprender. Por tanto,

inclinad vuestra oreja, quiero decir, vuestra razón, y no tengáis temor de ser engañada. Inclinalda a la palabra de Dios, que está dicha en toda la Sagrada Escriptura, y, si no la entendierdes, y os pareciere que va contra vuestra razón, no penséis que erró el Espíritu Santo que la dijo; mas sujetadle vuestro entendimiento, y creed que por la grandeza de ella vos no la podéis alcanzar. Y mirad que manda Dios por el profeta Esaías, que nuestro recurso sea a su santa Escriptura; y que a los que no hallaren según ella, no les nacerá la luz de la mañana. Porque, aunque en otras cosas puedan ser sabios sin tener ciencia de ella, mas tener conocimiento de Dios y de lo que cumple a nuestra salud, no se alcanza sino por la sabiduría de la palabra de Dios (AF III, 2: 475-6) $)^{9}$.

8. Son especialmente interesantes sus coincidencias básicas con el largo e importante apartado dedicado a la hermenéutica de la Sagrada Escritura en la Iglesia, Verbum Domini 29-49.

9. Todas las citas se hacen por la edición ya indicada, San Juan de Ávila, Obras completas. Nueva edición crítica I. AF se refiere a la edición del Audi filia de 1556, según sus partes, numeración de párrafos y páginas de la edición moderna citada; $2 \mathrm{AF}$ se refiere a la edición de 1574, con capítulo y numeración de párrafos y páginas de la misma edición moderna. Por lo que se refiere a este texto, en $2 \mathrm{AF}$ c. $45,3: 633$, se suprime la referencia a Isaías, que de hecho parece no encontrase en el texto bíblico, con todo el párrafo que sigue, justificando la última afirmación con una cita genérica de san Agustín, quizá Confesiones XIII, 15, o De civitate Dei XI, 5. 
Por tanto, y en segundo lugar, para el Maestro Ávila toda la Escritura es palabra de Dios, toda ha sido dicha por el Espíritu Santo y, en consecuencia, no puede contener errores. Se trata de la doctrina tradicional, si bien, como veremos enseguida, él precisa que en la Escritura no hay errores en cuanto se refiere a nuestra salvación. Por lo demás, quien no acuda a la Escritura en busca de luz (para la vida espiritual y la salvación), quedará en la oscuridad de la noche (de la vida carnal y de la condenación).

Pero, ¿por qué hemos de fiarnos en definitiva de la Escritura más que de cualquier otro argumento en lo que hace a la vida espiritual? El Maestro Ávila, con la experiencia de su largo magisterio y trato con diversas personas cristianas, sabe muy bien que sólo la Escritura es criterio para discernir en la vida espiritual si una revelación es verdadera o falsa. Y la razón que da para justificar esta afirmación nos ayuda a completar su visión de la Escritura Sagrada:

Hemos de dar mayor creencia que a criatura del cielo ni de la tierra a la Escritura divina, pues quien en ella habló es más alto y más verdadero que todos; y ella es el sello real que hace dar crédito a las revelaciones y dotrinas que concuerdan con ella, y es el cuño donde está la verdadera moneda de la verdad de Dios (AF III, 19: 484).

La afirmación es realmente sorprendente y refleja una familiaridad y confianza en la Sagrada Escritura muy grandes. Es cierto que, en el mismo párrafo, como luego veremos, indica que para la interpretación de la Escritura hay que guiarse por la luz del Espíritu Santo, «que alumbra a su Iglesia y a los santos dotores que en ella han hablado». En cualquier caso, y en tercer lugar, tenemos aquí un rasgo claro del teólogo humanista, que pone la Escritura como base de la teología y de la vida espiritual, al estilo de la propuesta de Erasmo en su Ratio seu methodus compendio perveniendi ad veram theologiam, donde define la teología como elucidatio Scripturae, recordando a la vez la necesidad de abrirse a Cristo, escucharlo y hacerse su discípulo, con el fin de comprender verdaderamente la Escritura. Para ello, prosigue el maestro holandés, el verdadero guía es el Espíritu Santo. De esta manera se llega a lo que Erasmo llama la vera theologia, la religión interior vivificada por Cristo ${ }^{10}$. Nada tiene de extraño, por tanto, que las afirmaciones del Maestro Ávila hayan desaparecido en la segunda edición, ya que no podía por menos de sonar a protestante a los susceptibles oídos de quienes asesoraban al tribunal de la Inquisición, y que haya sido sustituido por ejemplos patrísticos y de los padres del desierto (cf. 2AF c. 51: 646-8).

Finalmente, la reflexión del Maestro Ávila sobre la palabra de Dios no concluye en este punto, sino que ofrece otros rasgos de interés. Bien es verdad que, para ello, hemos de acudir a otros escritos, por ejemplo, a su tratado sobre el sacerdocio, escrito antes de 1563, probablemente sin conocer aún a fondo

10. Cf. L. BOuYeR, «Erasmus in relation to the Medieval Biblical Tradition», en The Cambridge History of the Bible II, Cambridge 1969, 492-508. 


\section{La Sagrada Escritura según San Juan de Ávila}

las decisiones conciliares de Trento. Así, si bien es verdad que toda la palabra de Dios se encuentra en la Escritura sagrada, en realidad la palabra de Dios por excelencia es Cristo. Lo afirma expresamente al recomendar a los sacerdotes que prediquen la palabra de Dios. A este propósito recalca que esta Palabra es, por excelencia, Cristo, «Palabra que del cielo descendió a este mundo (y) vino haciéndose hombre». Él es la «Palabra de Dios increada», y todos los bienes que como tal «obró en los cuerpos de los hombres y los que ganó por medio de su pasión para las ánimas, los obra y efectúa mediante su palabra que acá dejó» (Tratado sobre el sacerdocio 46-47, 945).

En resumen, aquí tenemos una primera visión relativamente completa de cómo él pensaba acerca de la Palabra de Dios: ella se encuentra en toda la Escritura; ella alcanza su cumbre en la Palabra encarnada e increada, que es Cristo; Cristo y su palabra, con toda su eficacia, se encuentra en la palabra que él nos dejó y que podemos encontrar en la Escritura, especialmente en los evangelios, «las benditas palabras del Verbo de Dios hecho carne» (AF III, 3: 476). Más adelante, recogeremos algunos apuntes de lo que para el Maestro Ávila significa predicar la palabra de Dios. Pero, antes, ahondemos en lo que para él son la naturaleza y las cualidades de la Sagrada Escritura.

\section{LA SAGRADA EscRITURA}

Como era de esperar, tampoco se encuentra una exposición teórica sobre la naturaleza de la SE, ni tiene por qué hallarse en una obra netamente espiritual y práctica, dirigida además a una persona que no es especialmente entendida en teología. Sin embargo, leyendo con atención, encontramos suficientes datos para reconstruir una concepción bastante completa de lo que la Escritura es. Así, ya en la introducción misma de la obra, cuando acaba de escribir las primeras palabras del salmo 44 , que son el punto de partida de todo su escrito, deja caer como algo bien sabido, que es Dios quien habla por medio de los escritores bíblicos, una forma concreta de expresar la inspiración bíblica:

Oye, hija, ve, e inclina tu oreja y olvida tu pueblo y la casa de tu padre. Y cobdiciará el rey tu hermosura (Sal 44, 11-12). Estas palabras, devota esposa de Jesucristo, dice el profeta David, o, por mejor decir, Dios en él, a la Iglesia cristiana, amonestándola de lo que ha de hacer para que el gran rey Jesucristo la ame, de lo cual a ella le siguen todos los bienes (AF, Introducción: 409; 2AF, c. 1, 1: 539)11.

Dos cosas conviene notar en este caso. En primer lugar, se afirma la inspiración del autor del salmo bíblico, que según la tradición admitida en este mo-

11. Las citas de los salmos, como las de otros textos bíblicos, se hacen según la numeración de la Vulgata, que es la Biblia que utiliza san Juan de Ávila. 
mento por judíos y cristianos, era David: Dios habla por los autores humanos de la Escritura. Aunque san Juan de Ávila dice que Dios habla por David, es evidente que se está refiriendo al salmo escrito. La interpretación correcta es, por tanto, que Dios habla por los autores que escriben la Sagrada Escritura. De aquí, como hemos visto antes, la afirmación de que la palabra de Dios está dicha toda en la Escritura; y la que también hemos ya indicado, de que Dios habla en toda la Escritura, haciendo de esa Palabra suya escrita la máxima autoridad. Hasta tal punto esto es así, que designa el texto bíblico con la singular expresión de «Escriptura de Dios» (AF III, 19: 484). En segundo lugar, no es sin importancia, la afirmación de que en la Escritura Sagrada Dios habla a su Iglesia cristiana. Es verdad, que tal afirmación pende, como es evidente, de la interpretación alegórica primera de este verso: el esposo y la esposa del salmo son, en primer lugar, Dios y la Iglesia; después, siguiendo la tradición iniciada con Orígenes y acogida por san Bernardo y toda la corriente mística cristiana, Dios y el alma. En cualquier caso, la afirmación de que Dios habla en la Escritura a su Iglesia forma parte de la comprensión que san Juan de Ávila tiene de la Escritura, comprensión que, como hemos de ver, tiene sus consecuencias.

Por otra parte, la cuestión del canon bíblico, tan debatida en Trento, y establecida con toda precisión en su sesión cuarta, no aparece de manera directa en este escrito. Se trata, al fin y al cabo, de una cuestión más bien técnica, que afecta más al teólogo que al simple fiel. No obstante, podemos rastrear su opinión en alguno de los pasajes de la edición segunda del Audi filia:

Y también habéis de saber que declarar cuál escritura sea palabra de Dios, para que por tal sea de todos creída, no pertenece a otro sino a la misma Iglesia cristiana, cuya cabeza en la tierra, por divina ordenación, es el Romano Pontífice (2AF c 46, 2: 635)

Las palabras del santo son precisas: la Iglesia no establece ni decide cuál Escritura sea palabra de Dios, sino que únicamente declara cuál lo es. Trento había afirmado que la Iglesia «recibe y venera» (suscipit et veneratur) las Escrituras santas y las tradiciones no escritas (EB 57) ${ }^{12}$. Con un lenguaje parejo, el Maestro Ávila afirma que es la Iglesia quien «declara» lo que es Escritura, no quien lo decide, pues esto es propio del Espíritu Santo, que habla por los autores sagrados, según acabamos de ver. Esta es la única alusión al canon bíblico que he encontrado en el escrito, si bien es importante, por lo preciso de su formulación. Tal declaración, prosigue el santo, debe acogerse con fe, escuchando cuanto nos enseña la Iglesia, porque fuera de la Iglesia no hay salvación. Y fundamenta la última afirmación en san Jerónimo y a partir de la clásica interpretación alegórica de las ocho personas refugiadas en el arca de Noé, según 1 Pe

12. Utilizo la reciente edición española de C. Granados y L. Sánchez Navarro, Enquiridion Bíblico. Documentos de la Iglesia sobre la Sagrada Escritura, Madrid, BAC 2010. 


\section{La Sagrada Escritura según San Juan de Ávila}

3, 18-22. En el siguiente párrafo, recordará que ésta es la fe de la Iglesia, y que de ella se apartan «herejes pasados, presentes o por venir», en una clara referencia sobre todo a la doctrina protestante y, en concreto, a la de Lutero, a quien desacredita severamente (2AF c. 46, 2-4: 635-6).

Pertenece también a su bagaje teológico-escriturístico la tradicional doctrina de la unidad de los dos Testamentos, el Antiguo y el Nuevo. En el mismo párrafo en que explica los criterios para discernir cuándo una revelación personal es auténtica o menos, el primero de ellos es el contraste con la Escritura completa:

Sea el primero, que la tal revelación o espíritu no venga sola, mas acompañada de la Escriptura de Dios, contenida en el Viejo y el Nuevo Testamento, y nuevas cosas conformes a la enseñanza y vida de Cristo y de los santos pasados (AF III, 19: 484).

El recurso a la Escritura, que aparece con tanta fuerza en la primera edición, desaparece en la segunda, como ya he tenido ocasión de notar. Sin embargo, su convicción de que la Escritura consta de Antiguo y Nuevo Testamento es afirmada también en la segunda, a la vez que subraya el fundamento para una interpretación cristológica de toda la antigua ley. Así, recomienda a quien dedica el libro, que sea estudiosa de las palabras que Dios pronunció en la Escritura, unas veces por medio de sus siervos (los profetas), después «en la humanidad que tomó», es decir, «por su propia persona: abriendo su propia boca para hablar (cf. Mt 5,2), el que primero había abierto y después abrió la boca de otros que en el Viejo Testamento y Nuevo hablaron» (2AF c. 45: 633). Toda la Escritura, por tanto, Antiguo y Nuevo Testamento es palabra pronunciada por Dios. Como dice bellamente en la primera edición, comentando el pasaje de la transfiguración (Mt 17), los dos testigos que quiso tener Cristo y los que deben acompañar como criterio de autenticidad cualquier revelación, son las dos partes de la Biblia:

De esta manera leemos que, cuando apareció Cristo en el monte Tabor, no fue solo, mas con copia de abonados testigos. No porque él los hobiese menester, pues es verdad inmutable ... Así, trayendo testigos el que no los hubo menester, se nos da a entender que no debemos recebir cosa ninguna de aquestas, si no trae por testigos al Viejo Testamento con sus profetas, que son figurados en Moisén y Elías, y al Nuevo y doctrina apostólica, figurado en san Pedro, san Juan y Santiago, que presentes estaban (AF III, 19: 484).

Esto no obsta para subrayar que las palabras del Señor, los evangelios, tienen una preeminencia clara para el cristiano:

Y aunque a toda la Escriptura de Dios hayáis de inclinar vuestra oreja con muy gran reverencia, mas inclinalda con muy mayor y particular devoción y humildad a las benditas palabras del Verbo de Dios hecho carne, abriendo vuestras orejas del cuerpo y del ánima a cualquier palabra de este Señor, particularmente dado a nosotros por maestro, por voz del Eterno Padre, que dijo: Éste es mi amado Hijo, en el cual me he aplacido, a él oíd (Mt 17, 5) (AF III, 3: 476; 2AF c. 45, 4-5: 633-4). 
Se trata de un punto que desarrolla algo más ampliamente en la edición segunda, aunque indicando ahora que sean otros quienes busquen esas palabras a la lectora para quien escribe «en la Sagrada Escritura, en doctrina de la Iglesia y dichos de los santos», reflejo probable este matiz de la prohibición ya vigente de acceder directamente a los evangelios para quienes no fueran clérigos.

En cualquier caso, conviene notar la plena coincidencia del Maestro Ávila acerca de la unidad de Antiguo y Nuevo Testamento con la tradición más antigua de la Iglesia, desde que ello se puso en discusión con Marción y fue reafirmada por san Justino y san Ireneo; y por supuesto, con la doctrina del Vaticano II (DV 16), quien también apunta la especial relevancia de los evangelios (DV 18).

\section{CuAlidades de LA SAgRAda Escritura}

Uno de los apartados clásicos del estudio acerca de la inspiración bíblica fue siempre el estudio de las consecuencias que de ello se derivaban en la Sagrada Escritura. Desgraciadamente, estas consecuencias, que son en el fondo una descripción de las cualidades de la Escritura, se transformaron, sobre todo en el siglo XIX ante los ataques provenientes de los avances de las ciencias positivas y de la crítica histórica, en una defensa apologética de la inerrancia bíblica. En tiempos del Maestro Ávila ninguna de estas cuestiones tenía un tratamiento teológico detenido. La primera obra que, tras el concilio de Trento, se dedica a hablar sistemáticamente de la Sagrada Escritura en la Iglesia católica es la Bibliotheca Sancta de Sixto de Siena, publicada en Venecia el año 1566, es decir, cuatro años después de finalizar el concilio. Aunque, naturalmente, existieron otros escritos anteriores, que ayudaban a conocer en conjunto la Escritura Sagrada, como puede verse en cualquier historia de los estudios de introducción a la Biblia, es en esta obra, donde se unen dos objetivos, que permanecerán en casi todos los tratados católicos posteriores de la materia: una exposición lo más completa posible tanto de los elementos necesarios para comprender los libros de la Escritura, como de cuantos son útiles para rebatir los escritos que se oponen a su recta comprensión. Pero en ella ni se habla detenidamente acerca de la inspiración bíblica, ni mucho menos de las cualidades de la Sagrada Escritura derivadas de ella ${ }^{13}$.

Y, sin embargo, las ideas y los conceptos que después se sistematizarán y se estudiarán con más detalle, ya están en los escritos del Maestro Ávila, incluso con matices que nos acercan sorprendentemente al concilio Vaticano II. Así, en el texto ya varias veces citado, donde expone el aviso primero para conocer las

13. Cf. mi trabajo «De la Introducción General a la Sagrada Escritura a la Teología de la Biblia. Una propuesta metodológica», en J.M. SÁNCHEZ CARO, coord., Palabra de Dios y Teología. XXI Conversaciones de Salamanca 2008, Salamanca, Universidad Pontificia de Salamanca 2010, 21-74 = Salmanticensis 56 (2009) 5-48. 


\section{La Sagrada Escritura según San Juan de Ávila}

revelaciones, la Escritura divina es más de fiar incluso que cualquier criatura del cielo y de la tierra,

pues quien en ella habló es más alto y más verdadero que todos; y ella es el sello real que hace dar crédito a las revelaciones y doctrinas que concuerdan con ella, y ella es el cuño donde está la verdadera moneda de la verdad de Dios, a la cual se ha de venir a examinar toda otra cosa para ser aprobada si fuere conforme, o reprobada si discordante (AF III, 19: 484).

El párrafo como tal ha desaparecido en la edición segunda, pero la afirmación de la verdad de la Escritura no solamente se afirma en ella, sino que encontramos algunos detalles de sumo interés y actualidad. Así, se afirma por supuesto, como ya hemos visto, que toda la Sagrada Escritura «es palabra de una misma suma Verdad» (2AF c. 45, 4: 633). Pero un poco más adelante se nos dan precisiones sobre el tipo de verdad de la Escritura. En el capítulo 48 se nos invita a acoger la palabra de Dios, pero no como lo hacen herejes como los luteranos, que son engañados por el demonio y acogen la mentira, aunque les parezca que son movidos a ello como si fuera "una muy grande y saludable verdad». Estos, así como los cristianos que no son consecuentes en su vida con la palabra de Dios en que creen, recibirán su castigo:

Pues en castigo de que no tuvieron amor a la verdad con la cual fueron salvos, poniendo en obra lo que ella enseñaba, que les sea quitada dejándoles creer el error es muy justo juicio de aquel Señor, que es terrible en sus consejos sobre los hijos de los hombres (Sal 65, 5) (2AF c. 48, 2: 639).

Dice después que ese error se apoya precisamente en la Escritura, con lo que la mesa de salvación se convierte en mesa de engaño y condenación:

Y si miráis dónde armó Dios el lazo con que los judíos y herejes fuesen castigados, según hemos dicho, pareceros ha cosa más para temblar que para hablar. Preguntaldes a éstos que en qué estriban para seguir su error con pertinacia tan porfiada; y deciros han los unos que en la Escritura sagrada del Viejo Testamento, y los otros que en la del Nuevo ... ¿Vistes nunca cosa tan al revés, tornarse la mesa de vida en lazo de muerte? ¿La mesa de consolación y perdón, en castigo? ¿La mesa do hay lumbre para saber andar el camino que lleva a la vida, tornarse en tropiezo para errar el camino y caer en la muerte? Grande es por cierto la culpa que tal castigo merece: que el hombre se ciegue en la luz y se le torne muerte la vida (2AF c. $48,3: 639-40)$.

Para el Maestro Ávila la Escritura, que es palabra de Dios, contiene no una verdad científica o histórica, sino la verdad salvadora. Acoger esa verdad lleva no a tener más conocimientos científicos, sino a alcanzar la salvación; dejarse seducir por el error, al contrario, no conduce a la ignorancia, sino a la condenación. Ésta parece ser la síntesis de sus afirmaciones, con lo que se subraya el papel propio de la verdad de la Escritura: la salvación. Cierto es que en todo 
este párrafo y en los siguientes está discutiendo, sin decirlo expresamente, con los que interpretan la Escritura a su libre albedrío, dejando fuera la norma de la Iglesia. Pero no lo es menos, que la consecuencia de ese error no es la de ser más o menos ignorantes, sino la de ir o no ir por el camino de la salvación. Así, la Escritura viene descrita como «mesa de vida», «mesa de consolación y perdón», «mesa do hay lumbre para saber andar el camino que lleva a la vida». Dicho de otra manera, para nuestro autor la Escritura es un libro religioso, palabra de Dios que, acogida en el seno de la Iglesia, lleva a la salvación. Y conviene subrayar, que esta concepción de la verdad de la Escritura coincide plenamente con una de las afirmaciones más importantes y originales del concilio Vaticano II acerca de la Escritura, a saber, que enseña «firmemente, con fidelidad y sin error, la verdad que Dios quiso consignar en las sagradas letras para nuestra salvación» (DV 11).

Esta convicción es, para nuestro santo, la razón fundamental de la utilidad pastoral de la Sagrada Escritura. Hay que predicar la palabra de Dios que está en la Escritura, porque ella nos acerca los bienes necesarios para la salvación. Así lo afirma expresa y bellamente en el alegato final, por desgracia incompleto, de su Tratado sobre el sacerdocio, escrito antes de finalizar el concilio de Trento:

Todos estos bienes que la Palabra de Dios increada obró en los cuerpos de los hombres y los que ganó, mediante su pasión, para las ánimas, los obra y efectúa mediante su palabra que acá dejó. Con ésta alumbra nuestras ignorancias, encienda nuestra tibieza, mortifica nuestras pasiones y, lo que más es, resucita las ánimas muertas, que es mayor obra que criar cielos y tierra... (Tratado sobre el sacerdocio n. 47: I, 945).

Y ésta es también la razón por la cual el sacerdote debe tener un conocimiento suficiente, aunque no sea especializado, de la Escritura, esto es, que sea

medianamente docto en la ley de Dios, que está en la santa Escritura, porque en ella está lo que conviene para estos efectos, como dice san Pablo: Omnis Scriptura divinitus inspirata... (2 Tim 3, 16); y así conviene que sepa la sagrada Escritura, aunque no las dificultades, mas lo llano de ella. ... . . ... conviene que el cura sea leído en la lección moral de los santos, pues sin ella ni entenderá seguramente la sagrada Escritura y hará muchos yerros en la cura de ánimas, por no aprovecharse de los avisos de los médicos que Dios nos dio» (Tratado sobre el sacerdocio n. 38: I, 940-1)

Añadamos un último apunte significativo y lógico, teniendo en cuenta la cualidad de maestro espiritual de san Juan de Ávila. No sólo para la predicación es útil y necesaria la Escritura, sino que es imprescindible para avanzar en la vida espiritual, pues es en ella donde escuchamos a Dios que nos habla, y ella es la que nos da la sabiduría eficaz («una singular medicina», dice en la segunda edición) que lleva a la salvación: 


\section{La Sagrada Escritura según San Juan de Ávila}

Y mirad que manda Dios por el profeta Esaías, que nuestro recurso sea a su santa Escriptura; y que a los que no hallaren según ella, no les nacerá la luz de la mañana. Porque, aunque en otras cosas puedan ser sabios sin tener ciencia de ella, mas tener conocimiento de Dios y de lo que cumple a nuestra salud, no se alcanza sino por la sabiduría de la palabra de Dios ... Y aunque a toda la Escriptura de Dios hayáis de inclinar vuestra oreja con muy gran reverencia, mas inclinalda con muy mayor y particular devoción y humildad a las benditas palabras del Verbo de Dios hecho carne ... Sed estudiosa de leer y oír con atención y deseo de aprovechar estas palabras de Jesucristo. $\mathrm{E}$ sin duda hallaréis en ellas una excelente eficacia que obre en vuestra ánima, la cual no la hallaréis en todas las otras, que desde el principio del mundo Dios ha hablado ni ha de hablar hasta el fin de él (AF III, 2: 475-6; con pequeñas variantes $2 A F$ c. 45, 3-6: 632-4).

Así pues, según san Juan de Ávila, la Sagrada Escritura es absolutamente verdadera, más de fiar que cualquier criatura del cielo y de la tierra, pues ella es el cuño de la verdad de Dios. Pero no se trata de una verdad científica o histórica, sino de la verdad que conduce a la salvación. En este sentido es palabra eficaz para fundamentar en ella la predicación, medicina singular para las enfermedades del alma y guía excelente hacia las cumbres de la vida espiritual.

\section{PRINCIPIOS DE INTERPRETACIÓN DE LA SAGRADA ESCRITURA}

Si había alguna cuestión candente en la Iglesia de la segunda mitad del siglo $\mathrm{XVI}$, cuando vive, escribe y predica san Juan de Ávila, ésa era la interpretación de la Escritura. Por una parte, la recuperación de la Sagrada Escritura en el estudio teológico y en la piedad, promovida por los humanistas y, en especial, por Erasmo de Rotterdam, era un potente impulso para la lectura de la Biblia en todos los campos de la vida cristiana, ya que se trata del texto de mayor autoridad para el creyente; de aquí, el optimismo ante la lectura de la Biblia y el deseo de conocerla cada vez mejor. Por otra parte, la reforma protestante de Lutero y demás reformadores, al apoyarse únicamente sobre la Escritura, rechazando cualquier otra autoridad de la Iglesia, por considerarla humana y, en consecuencia, corrompida por el pecado original y falible, vino a truncar este renacimiento bíblico en el mundo católico y puso en guardia a las autoridades, concretamente al tribunal de la Inquisición. San Juan de Ávila es testigo y protagonista de esta historia. Su primera redacción del Audi filia rezuma optimismo bíblico por los cuatro costados y expresa la doctrina tradicional de la Iglesia en términos sorprendentemente parecidos, en algunos casos idénticos, a los que hoy recoge el concilio Vaticano II en su constitución sobre la revelación divina. Nada de extraño que la obra acabase en el severísimo índice de libros prohibidos de Valdés del año 1559 , entre otras cosas, porque no era fácil distinguir la libre interpretación propuesta por los reformadores protestantes y el tipo de lectura e interpretación que en nuestra obra se describe. En consecuencia, el optimismo bíblico se reduce 
en la segunda edición. No cambia nuestro escritor sustancialmente la doctrina ya escrita; pero se hace más cauto, suprime expresiones que podrían malinterpretarse y acentúa la necesidad de interpretar la Escritura en consonancia con la Iglesia y su magisterio. Pero, incluso en este caso, su enseñanza resulta sorprendentemente moderna y siempre actual. Veamos brevemente cuáles son los principios de hermenéutica bíblica que se exponen en esta bella obra espiritual, anotando siempre las diferencias entre la primera y la segunda edición.

Lo primero y fundamental para san Juan de Ávila es que la Sagrada Escritura es palabra de Dios. En consecuencia, no basta la razón para poder acercarse a ella y entenderla, sino que se requiere acogerla con fe. $Y$ eso es lo que da a entender, según su explicación, la expresión «inclina tu oído» del salmo 44:

En la cual (frase) nos da a entender que debemos profundamente sujetar nuestra razón, y no estar yertos en ella, si queremos que el oír y ver no nos sea ocasión de perdición. Porque es cierto que muchos han oído palabras de Dios, y han tenido claros entendimientos de cosas sutiles y altas, y porque se arrimaron más a la vista que a inclinar la oreja, tornóseles la luz en ceguedad y tropezaron en luz de mediodía como si fuera tinieblas. Por eso, ánima, que no queréis errar en el camino del cielo, inclinad vuestra oreja, quiero decir, vuestra razón, y no tengáis temor de ser engañada. Inclinada a la palabra de Dios, que está dicha en toda la Sagrada Escriptura ... Y habéis de mirar que la exposición de esta Escriptura no ha de ser por seso o ingenio de cada cual, que de esta manera qué cosa habría más incierta que ella, pues comúnmente suele haber tantos sentidos cuantas cabezas; mas ha de ser por la determinación de la Iglesia católica, a interpretación de los santos de ella, en los cuales habló el mismo Espíritu Santo declarando la Escriptura, que habló en los mismos que la escribieron. Porque, de otra manera, ¿cómo se puede bien declarar con espíritu humano lo que habló el Espíritu divino? Pues que cada Escriptura se ha de leer y declarar con el mismo Espíritu con que fue hecha (AF III, 2.3: 475-6).

El párrafo no tiene desperdicio. El santo Maestro recuerda que la Sagrada Escritura, por ser palabra de Dios, necesita de algo más que la razón y el entendimiento para poder ser desentrañada. No es que rechace el necesario estudio y la conveniente preparación racional. Como luego veremos, ello también es necesario. Pero no basta. Querer entender la Escritura sólo con la razón nos lleva a opiniones y sentencias sin fin sobre la interpretación de cada pasaje. La interpretación cierta sólo puede encontrarse en la Iglesia. La razón de ello, es que en la Iglesia sigue hablando por sus santos el mismo Espíritu que habló en la Escritura. Y es con la luz de este Espíritu, y no con la del puro espíritu humano, como puede entenderse adecuadamente la Escritura. Y, tras este razonamiento, enuncia lo que es el principio básico de la hermenéutica bíblica: toda Escritura se ha de leer e interpretar con el mismo Espíritu con que fue escrita. Exactamente el principio que cuatrocientos años después iba a plasmar como base de toda interpretación bíblica la constitución dogmática sobre la revelación, Dei Verbum, del concilio Vaticano II (cf. DV 12). 


\section{La Sagrada Escritura según San Juan de Ávila}

La historia de este principio es larga y ha sido expuesta recientemente por los comentaristas de la constitución Dei Verbum. Su origen es el comentario de san Jerónimo a la carta de san Pablo a los Gálatas, donde recuerda que no se puede entender la Sagrada Escritura «de modo distinto al que exige el sentido querido por el Espíritu Santo, en que fue escrita» ${ }^{14}$. Es posible que éste sea el origen de la frase en el Maestro Ávila, quien sin embargo no hace referencia alguna a san Jerónimo y a su comentario a Gál, donde la frase es sólo un inciso. Ésta aparece también casi literal en la Imitación de Cristo, libro que él mismo tradujo, y que cita literalmente en el segundo memorial para el concilio de Trento ${ }^{15}$. Pero allí se trata del espíritu, es decir, de la actitud espiritual con que hay que leer la Biblia, no del Espíritu Santo, como acertadamente interpreta aquí nuestro autor. Por eso, la frase que aparece en el Audi filia se refiere no a una actitud espiritual del lector, sino a un principio básico hermenéutico, que además él aclara de manera profundamente teológica: interpretar la Escritura con el mismo Espíritu que fue compuesta es interpretarla de acuerdo con la Iglesia, porque en ella, en sus santos habita, y en ella habla el mismo Espíritu que hizo nacer la Escritura sagrada.

Es notable esta doctrina, que complementa en cierto modo y fundamenta la respuesta de Trento y de la autoridad eclesiástica española a la libre interpretación de la Biblia, es decir, sólo con la ayuda e iluminación del Espíritu y sin intervención de la Iglesia. Por otro lado, nada tiene de particular que muchas de las expresiones que en esta interesante página de la primera edición del Audi filia estamos estudiando, se modificaran sustancialmente en la segunda. Efectivamente, en el pasaje paralelo la redacción, como ya he notado, es totalmente distinta. Y lo mismo en todo el conjunto. El acento ahora recae en la necesidad de interpretar la Escritura ateniéndose a cuanto enseña la Iglesia. Los tiempos no

14. En el proyecto cuarto de lo que sería después la Dei Verbum del concilio Vaticano II, se dice literalmente: ... et non aliter Scripturam intelligendam esse 'quam sensus Spiritus Sancti flagitat, quo conscripta est'; y se hace referencia explícita en nota al comentario de san Jerónimo a la carta a los Gálatas 5, 19-21; PL 26, 445. El texto ya había sido utilizado por el papa Benedicto XV en su encíclica Spiritus Paraclitus, donde con esta frase se exhortaba a los exegetas católicos a tener una actitud religiosa, humilde y dócil ante la Escritura (cf. EB 469). El texto completo de san Jerónimo en su comentario a Gálatas, donde la frase es solamente un inciso, dice así: "Quienquiera, pues, que entienda la Escritura de otro modo que como exige el sentido del Espíritu Santo, en que fue escrita, aunque no se aparte de la Iglesia, puede sin embargo ser llamado sectario»; cf. A. ARTOLA - J.M. SÁnCHEZ CARO, Biblia y Palabra de Dios. Introducción al Estudio de la Biblia 2, Estella, Verbo Divino, c. XII, III.

15. TH. DE KEMPIS, De imitatione Christi libro quatuor. Munich, ex typographia Bergiana 1591, 32; c. 5, 1: Veritas est in Scripturis sanctis quærenda, non eloquenda. Omnis Scriptura sacra eo spiritu debet legi, quo facta est. Quærere debemus potius utilitatem in Scripturis, quam subtilitatem sermonis... ; en la traducción de san Juan de Avila: «En las Santas Escrituras se debe buscar la verdad y no la elocuencia. Cualquier Escritura se debe leer con el espíritu que se hizo, y más debemos buscar en ellas el provecho que la sutileza...», cf. SAN JUAN DE ÁvILA, Obras completas. Nueva edición crítica II, 892; la cita del Maestro Ávila en Memorial segundo al Concilio de Trento 67: II, 591, interpretada correctamente según el sentido de Kempis. 
eran fáciles y la vigilancia doctrinal, en particular sobre todo lo referente a la lectura e interpretación de la Escritura sagrada, era extrema. Por eso, aunque no cambia sustancialmente la doctrina sobre la necesidad de la Sagrada Escritura para tener guía exacta de vida espiritual, en la segunda edición las expresiones son más cautas, menos vivas, subrayando el papel de la Iglesia en lo que se refiere a la interpretación de la Sagrada Escritura y a la declaración sobre el canon bíblico. Sin duda, es una corrección de matices a partir de la doctrina de Trento y, con toda seguridad, de las observaciones que le hicieron a la primera edición de su obra. En ésta la enseñanza sobre la Escritura es más fresca y viva, más en el estilo del Vaticano II, con alguna de cuyas afirmaciones, como hemos visto, casi coincide hasta en la letra; la doctrina de la segunda edición, no cambiando en lo sustancial, es más matizada y, sin dejar de subrayar la importancia de la Sagrada Escritura, se insiste más en el papel de la Iglesia, que aquí es entendida siempre como iglesia jerárquica, con el papa al frente.

Pero precisamente su esfuerzo por conjugar la lectura e interpretación de la Biblia «en Espíritu» con la obediencia a la Iglesia, le conduce a ahondar en la relación que hay entre ambas realidades con un detalle y una precisión que no existían en la edición primera. Oigamos estas palabras, que nacen tanto de la fuerte convicción de la necesidad de contar con el Espíritu para interpretar la Biblia, como de la no menos fuerte convicción de que es necesario escuchar y obedecer a la Iglesia. El punto de contacto, ya sugerido en la primera edición y aquí expresado más ampliamente, es justamente que en la Iglesia habita y habla el mismo Espíritu autor de la Sagrada Escritura:

Habéis de saber que la exposición de la Escritura divina no ha de ser por seso o ingenio de cada cual; porque de esta manera, aunque ella en sí sea certísima, pues es palabra de Dios, sería, para lo que toca a nosotros cosa muy incierta, pues comúnmente suele haber tantos sentidos como cabezas. ... A sola la Iglesia católica es dado este privilegio, que interprete y entienda la divina Escritura, por morar en ella el mismo Espíritu que en la Escritura habló. Y donde la Iglesia no determina, hemos de seguir la concorde y unánime interpretación de los santos, si no queremos errar. Porque, de otra manera, ¿cómo se puede bien entender con espíritu ni ingenio humano lo que habló el divino, pues cada escritura se ha de leer y declarar por el mismo espíritu con que fue hecha? (2AF, c 46, 1: 634-5).

Los subrayados son del editor, que reproduce el original. Es muy posible que sean del mismo Ávila, quien, por razones que desconocemos, no puso la referencia a san Jerónimo en este punto. Pero el razonamiento del autor es de una gran coherencia y belleza, y responde plenamente a la doctrina actual del concilio Vaticano II, tal como ya he indicado. El santo ha intentado compaginar, tal como enseñaba el concilio de Trento (EB 62), la doctrina tradicional de la interpretación de la Escritura en el Espíritu con el mayor acento puesto en la obediencia a la Iglesia, la única que puede interpretarla de manera auténtica. Podría haber eliminado toda referencia a la Escritura. No lo ha hecho, porque está con- 


\section{La Sagrada Escritura según San Juan de Ávila}

vencido de que ella es manantial de la verdadera espiritualidad y fuerza de la predicación auténtica. Por eso, y teniendo en cuenta que escribe a quien no es clérigo, entendemos bien la conclusión de este capítulo de la segunda edición con palabras reveladoras de la situación:

Y mirad no caigáis en curiosidad de querer saber más de lo que habéis menester para vos, o para la gente que tenéis a cargo; porque lo otro debéislo dejar para los que tienen cargo de enseñar al pueblo de Dios, como amonesta san Pablo, que nuestro saber sea con templanza (Rom 12, 3) (2AF, c. 45, 6: 634).

Resta, en fin, completar este panorama con la necesidad de tener sentido de Iglesia y santidad de vida, sin olvidar, como dice al final del mismo capítulo, formarse y conocer lo mejor posible la Escritura y sus intérpretes, así como los instrumentos necesarios para estudiarla. Es lo que llama con expresión bien significativa el «grande aparejo» necesario para afrontar tamaña tarea:

Y grandes mercedes nos hiciste en darnos tu divina Escritura, tan provechosa y necesaria para te servir. Mas porque, siendo el viento que en este mar sopla viento del cielo, y quisieron algunos navegar por él con vientos de tierra, que son ingenios y estudios, ahogáronse en él, permitiéndolo tú ... Temida, y muy temida, debe ser la entrada en la divina Escritura, y nadie se debe arrojar a ella sin mucho aparejo, como a cosa en que hay mucho peligro. Lleve quien hobiere de entrar en ella el sentido de la Iglesia católica romana, y evitará el peligro de la herejía. Lleve, para aprovecharse de ella, limpieza de vida, como dice san Atanasio por las palabras siguientes: «Necesaria es la bondad de vida y limpieza de ánima, y cristiana piedad, para la investigación y verdadera ciencia de las Escrituras»...

Insiste después en la necesaria santidad de vida para alcanzar la verdadera sabiduría,

para que, con la lección de la Escritura y larga experiencia, pueda enseñar a los otros, a manera de testigo de vista, y dar en la vena del ajeno corazón, enseñando lo que pasa por el suyo.

Y concluye el capítulo recordando la necesidad de adquirir una adecuada preparación:

Conviene también ayudarse el hombre que quiere estudiar la divina Escritura del socorro y exposición de los santos, y aun de escolásticos; porque lo que del estudio de la divina Escritura se saca, sin llevar estas cosas, probádolo ha Alemania, mas por su mal (2AF c. 48, 4.6: 640-1).

Él mismo no tiene inconveniente en utilizar las ciencias del momento, para explicar algún texto de la Escritura (en este caso especialmente Jn 15, 14), como hace en una de las pláticas dirigidas a sacerdotes, acudiendo a los conocimientos de filosofía y psicología del momento. Así, intenta hacer entender lo que sig- 
nifica amar a Dios, disertando sobre las dos capacidades o potencias para amar, la espiritual y la corporal o concupiscible (Plática 10: Seréis mis amigos si guardáis mis mandamientos: I, 867-8). Y recuerda que el sacerdote ha de ser

medianamente docto en la ley de Dios, que está en la santa Escritura, porque en ella está lo que conviene para estos efectos, como dice san Pablo: Omnis Scriptura divinitus inspirata... (2 Tim 3, 16); y así conviene que sepa la sagrada Escritura, aunque no las dificultades, mas lo llano de ella ... Y ... conviene que el cura sea leído en la lección moral de los santos, pues sin ella ni entenderá seguramente la sagrada Escritura y hará muchos yerros en la cura de ánimas, por no aprovecharse de los avisos de los médicos que Dios nos dio (Tratado sobre el sacerdocio 38: I, 940-1).

Sobre los que sin preparación se atreven a interpretar la Escritura, tiene una página llena de ironía en la segunda edición del Audi filia, que no puede pasarse por encima. En el capítulo 53 presenta a algunos que son autosuficientes, «desafían y desprecian a todos los sabios, como Goliat al pueblo de Dios (cf. 1 Sam 17, 8-10)», creen no necesitar ayuda de nadie y

traen en la boca casi a la continua: «Esto me dice el Espíritu», «Dios me satisface», y semejantes palabras; otras veces alegan la Escritura de Dios, mas no la quieren entender como la Iglesia y los santos la entienden, mas como a ellos les parece, creyendo que no tienen ellos menor lumbre que los santos pasados, antes que los ha tomado Dios por instrumento para cosas mayores que a ellos (2AF 3, 2: 650-1).

En el capítulo siguiente aclara quiénes son los que se atreven a actuar de esa manera tan presuntuosa:

Habéis de saber que algunos de estos que he dicho en el capítulo pasado son gentes sin letras y cordialmente enemigos de los letrados. $Y$, si por ventura saben algún poco de latín, para leer y traer consigo un Testamento Nuevo, es tanto lo que se creen a sí mismos, pensando que creen a Dios ... Y son tan atrevidos e impersuasibles que, como la Escritura dice, mejor es encontrar con la osa que le han tomado los hijos, que a un necio que confía en su necedad (Prov 17, 12). Y tienen muy en la memoria, y también en la lengua, aquel dicho de san Pablo: $L a$ ciencia hincha, y la caridad edifica (1 Cor 8, 1). Y con esto paréceles tener licencia de despreciar a los sabios como a gente hinchada, y précianse a sí mismos como a gente llena de caridad; y no advierten que están ellos hinchados con soberbia de santidad, que es más peligrosa que soberbia de letras, como cosa que nace de cosa mejor, y por eso es ella peor (2AF c. 54, 1: 651).

Finalmente, y por cerrar esta serie de advertencias realistas, en el Memorial segundo al Concilio de Trento o Tratado de las causas y remedios de las herejías, escrito a punto de concluir el concilio de Trento, en 1561, al hablar de la soberbia de los que se han rebelado contra la Iglesia, vuelve a la carga, advirtiendo que para evitar las herejías es necesaria mucha ciencia y nunca fiarse de sí mismo, alegando recibir en directo la unción e iluminación del Espíritu Santo: 


\title{
La Sagrada Escritura según San Juan de Ávila
}

\begin{abstract}
$\mathrm{Y}$, si alguno dice que no sigue estos errores por autoridad de quien los enseña, sino que por su propio juicio los tiene por verdaderos, en ninguna razón cabe que uno sin estudio de letras sagradas y sin lo que se requiere para bien las entender, que es mucho, y mayormente una moza tonta o vieja vana, o un hombre de vulgo, tengan por más acertado lo que les parece que lo que les pareció a tan gran número de sabios y santos, de grandes ingenios y ejercitados en aquestas cosas. ¿Quién sufriría que en facultad de medicina o derechos, de arte militar o cosa semejante, habiéndose dubdado y disputado una cuestión por los sabios que ha habido en ella de mil o dos mil años acá, o después que hobiesen todos convenido, al cabo de mucha deliberación, en la determinación de ella, que viniese ahora un hombre indocto en aquella facultad o una mujer vana, y que de presto determinase lo que los sabios en tanto tiempo no habían sabido determinar o, lo que peor es, reprobase lo que ellos habían determinado?

$\mathrm{Ni}$ se puede esto paliar con que unctio docet de omnibus (cf. 1 Jn 2, 20). Porque, pues es divina ordenación que en la Iglesia unos enseñen y otros sean enseñados ... así no quiere san Juan decir en la dicha autoridad que la lumbre del Espíritu Santo inmediatamente enseñe a todos todas las cosas (Causas y remedios de las herejías 21-22: II, 545-6).
\end{abstract}

De nuevo, estas dos condiciones, además de la acogida creyente de la palabra de Dios en la Escritura, para que nuestra interpretación bíblica esté garantizada: el estudio o ciencia proporcionada y la confianza y obediencia a la Iglesia; la unción e iluminación del Espíritu, su «lumbre» como él escribe, y el estudio competente y la escucha de los expertos. Y todo ello, en la Iglesia, que es, como antes hemos visto que dice, la casa donde habita el mismo Espíritu, que inspiró la Sagrada Escritura y que inspira ahora su lectura viva y actual.

\section{DIVERSOS MODOS DE INTERPRETAR LA SAGRADA ESCRITURA}

El uso que de la Escritura hace Juan de Ávila en el Audi filia y en sus otras obras es muy variado, y recorre todos los procedimientos habituales en su tiempo. Es capaz de hacer una exégesis literal rigurosa, de acuerdo con los criterios de su época, sobre todo cuando se trata de textos paulinos o evangélicos; y abunda en diversos modos de interpretación espiritual de la Escritura, alegórica, tipológica, incluso buscando a veces sentidos acomodaticios, sin desdeñar el uso del gran acervo de historias bíblicas como fuente de ejemplos para sus predicaciones y escritos. Expondré estos modos de interpretación bíblica con ejemplos tomados preferentemente de su más importante obra sobre la vida espiritual.

\section{Interpretación literal, espiritual y teológica}

Hablo de interpretación literal, añadiendo después los adjetivos «espiritual» y «teológica», porque ambos delimitan y describen a la vez el sentido literal de los textos bíblicos, tal como se entendía en este tiempo. El sentido literal se en- 
tiende con categorías agustinianas y tomistas. Es el sentido inmediato del texto en su contexto y en el contexto general de la Escritura, de acuerdo con la tradición teológica. Es verdad que podría acentuarse el aspecto filológico, como usan no pocos de los escrituristas humanistas y como pedía Erasmo. No es este el caso de san Juan de Ávila. Si sabía griego o no, es discutible. En cualquier caso no parece que fuera mucho su conocimiento, y menos aún de la lengua hebrea. Al menos, nada de ello se transparenta de manera directa en sus escritos, ni siquiera en los llamados "Comentarios bíblicos», que son más bien una lectura continua de un par de libros bíblicos en clave de vida espiritual ${ }^{16}$. En la segunda edición del Audi filia encontramos la única alusión a esta cuestión. Así, a propósito de la exposición de Cant 1, 8, dice:

El cual lugar os declararé, según la letra griega y edición Vulgata, a la cual el Concilio Tridentino nos manda seguir, puesto caso que, según la letra hebrea, tenga otro sentido (2AF c. 57,1 : 658).

A mi modo de ver, esta observación, única en su obra, no exige que el Maestro Ávila tuviese un buen conocimiento de las lenguas griega y hebrea. El autor parece pensar que este verso, traducido directamente del hebreo, tiene otro sentido diferente al de la versión griega y al de la Vulgata. En realidad, san Jerónimo ha traducido Cant directamente del hebreo, aunque a veces se haya ayudado de las versiones latinas antiguas o Vetus latina. La diferencia entre el original hebreo y la versión latina es mínima y el sentido es prácticamente el mismo. Esto nos está indicando que la observación del comentarista no se basa en su conocimiento lingüístico, sino en otro factor. Que esto sea para desviar la atención de la versión de este paso por Erasmo en su Enchiridion, como propone el editor moderno, es muy posible ${ }^{17}$. En cualquier caso, es una clara referencia a la declaración de la Vulgata como versión latina «auténtica», hecha por el concilio de Trento (EB 61).

En este sentido, la mayoría de las veces que explica textos paulinos, y son muchísimos, dado su manifiesto paulinismo, nos vamos a encontrar con una interpretación en clave teológica o espiritual, pero siempre literal. Por ejemplo, es muy bella y muy oportuna la explicación de Rom 8, 31-34 ( «Si Dios con nos, ¿quién será contra nos?...»), recordando cómo nuestra esperanza de perdón y salvación es firme y se apoya en el amor que Dios nos ha manifestado al entregar a su Hijo por nosotros:

Y pues Dios nos perdona, ¿qué aprovecha que el demonio dé voces pidiendo justicia? Ya una vez fue hecha justicia de todos los pecados del mundo; la cual cayó sobre el inocente cordero, que es Jesucristo, para que todo culpado que quisiese

16. Véase la discusión de estos puntos en la introducción al volumen II de la edición de sus escritos ya citada, Obras completas. Nueva edición crítica II, 6-8.

17. Cf. la introducción al Audi filia en San Juan de Ávila. Obras completas I, 399. 


\section{La Sagrada Escritura según San Juan de Ávila}

llegarse a él sea perdonado. Pues, ¿qué justicia sería castigar otra vez los pecados del penitente con infierno, pues ya una vez fueron suficientemente castigados en Jesucristo? Él nos es dado por la misericordia del Padre, y en él tenemos todas las cosas; porque en comparación de tal persona divina, como es el Hijo, ¿qué es todo lo demás sino menos que él? Y quien dio el Señor, también dará el señorí; y quien dio el sacrificio, dio el perdón; y quien dio al Hijo, dará todo cuanto quisiéremos (cf. Rom 8, 32) (AF I, 42: 24-5).

También literal y acertadamente interpreta 1 Cor 1, 21, acerca de la sabiduría de este mundo (AF III, 1: 475). Y así en prácticamente todos los textos paulinos. A veces se ayuda de alguna autoridad, especialmente san Agustín, como cuando interpreta $1 \mathrm{Tim}$ 1, 5. En este caso Pablo dice que la orden dada a Timoteo, para que evite que se discutan doctrinas diferentes a la ortodoxa, nace de la caridad, «que procede de puro corazón y conciencia buena y fe no fingida». El término «conciencia buena» lo interpreta con san Agustín de la esperanza, «para darnos a entender que, si no hay buena conciencia, teniendo fe y amor y buenas obras que de aquí proceden, no habrá viva esperanza que nos dé alegría» (2AF c. 23, 5: 588). En ocasiones, apoyándose en el sentido literal, deduce una enseñanza moral, que por otra parte estaba ya en el texto. Así, por ejemplo, en el comentario a Lc 13, 1-5, acerca de «unos hombres que contaban a nuestro Señor que Pilato había muerto a cierta gente de Galilea en mitad de unos sacrificios que hacían, y llevaban los que esto contaban un liviano complacimiento en su corazón, con que se tenían por mejores que aquellos que habían hecho cosas merecedoras de que los matase Pilato». El comentarista, ayudado de Rom 11, 19-21, saca una breve conclusión moral: «Los castigos de Dios, hechos en otros, humildes y cautos nos deben hacer, no soberbios» (2AF c. 49, 1-2: 641).

Las polémicas interpretaciones de los reformados acerca de la justicia y la justificación, apoyándose en textos paulinos, no podían por menos de dejar eco en la lectura que san Juan de Ávila hace de esos textos. Un ejemplo de esta discusión, así como de la finura de su exégesis lo encontramos cuando explica 1 Cor 1, 30: «Cristo nos es hecho sabiduría, justicia, santificación y redención». El santo afirma que este modo de hablar de la Escritura no debe ser ocasión para pensar «que los justos no tienen en sí propia justicia», que es la tesis reformada. Nuestra justicia, según ellos, sería la justicia de Cristo, que cubre nuestros pecados, pero no nos hace radicalmente justos. Esta es la exégesis del Maestro Ávila:

Porque, si por eso somos justos, porque Cristo es justo, y no por justicia que tengamos, también se dirá que no hay sabiduría en nosotros, con que seamos sabios, ni santificación, ni redempción. San Juan dice que la unción del Espíritu Santo, que enseña todas las cosas, está en los justos (1 Jn 2, 20.27). San Pablo dice: Lavados estáis, santificados estáis (1 Cor 6, 11). Y san Pedro dice: Redemidos estáis de vuestra vana conversación (cf. $1 \mathrm{Pe} 1,18$ ). Pues, como Cristo no fue redimido, pues no tuvo pecado, de (ahí) que esta redempción ha de estar en no- 
sotros, por la cual somos llamados redemidos, no obstante que la Escritura diga que Cristo nos es hecho redempción. Porque en esto, y en las otras tres palabras, lo que quiere decir es que, por su merecimiento, nos son dadas aquestas cosas (2AF c. 91, 1: 735).

El texto es un buen ejemplo de su interpretación literal, usando otros textos bíblicos para aclarar el que parece oscuro ${ }^{18}$. De este modo, san Juan de Ávila se atiene al contenido y unidad de toda la Escritura, como sigue haciéndolo en todo este admirable capítulo, para concluir con una referencia al principio de la analogía de la fe:

$Y$ de esta manera se concuerda lo que el Concilio Tridentino dice que la justicia es nuestra, porque por ella, sujectada en nosotros, somos justificados; y lo que el Señor aquí dice, y en otra parte: La palabra que oístes no es mía (Jn 14, 24). Porque, aunque esté en nosotros, no la tenemos de nosotros, sino dada de la mano de Dios; y por eso se dice ser justicia de Dios (2AF c.91, 6: 737).

En algunos casos nos muestra que conoce cómo interpretar algunas expresiones bíblicas de origen semita. Así, cuando recuerda que «el nombre quiere decir la cosa misma» (Plática 4: Recordar e imitar la pasión de Jesucristo 2: 827). En otros, partiendo de textos del Antiguo Testamento, hace un bello recorrido por ellos, para mostrar su plenitud en el Nuevo. Esto es lo que sucede, por ejemplo, cuando en el Tratado del amor de Dios explica el amor que Dios nos tiene a partir de varios pasajes veterotestamentarios, tratados literalmente y leídos con profundo sentido espiritual. Es uno de los momentos más bellos de su exégesis, apoyando una doctrina (el amor singular que Dios nos tiene) en textos del Antiguo Testamento de una gran belleza y densidad. Veamos un breve extracto de este modo de tratar la Escritura:

La causa que más mueve el corazón al amor de Dios es considerar profundamente el amor que nos tuvo Él, y con Él su Hijo benditísimo, nuestro Señor. (...) Pues veamos agora, Señor, si Vos me amáis; y si es así que nos amáis, qué tanto es el amor que nos tenéis (...) Porque ansí como tú solo eres bueno por la eminencia de tu soberana bondad, así tú solo eres Padre; y de tal manera lo eres y tales obras haces, que, en comparación de tus entrañas paternales, no hay alguno que pueda ansí llamarse.

Bien conocía esto tu profeta cuando decía: Mi padre y mi madre me dejaron, y el Señor me recibió (Sal 26, 10). Tú mesmo te quisiste comparar con los padres, diciendo por Esaías: ¿Por ventura habrá alguna mujer que se olvide del niño chiquito, y no tendrá piedad del hijo que salió de sus entrañas? Posible será que se olvide, mas yo nunca me olvidaré de ti, porque en mis manos te tengo escripto y tus muros están delante de mí (Is 49, 15-16). Y porque entre las aves el águila es más

18. El mismo texto y con parecidos argumentos lo interpreta de la misma manera en la Plática 4, Recordar e imitar la pasión de Jesucristo 10-11: I, 831-2. 


\section{La Sagrada Escritura según San Juan de Ávila}

afamada en amar a sus hijos, con el amor de ella nos quisiste comparar las grandezas de tu amor: Así como águila, defendió su nido, y como a sus pollos, extendió sus alas y trujo sobre sus hombros (Dt 32, 11).

Sobre este amor es el del esposo a la esposa, del cual se dice: Por éste dejará el hombre a su padre, y se llegará a su mujer, y serán dos en una mesma carne (Gén 2, 24); mas a éste sobrepuja tu amor; porque, según dices tú por Hieremías, si el marido echa a su mujer de casa y, si echada, se junta con otro, ¿por ventura volverá otra vez a él? Mas tú has fornicado con cuantos amadores has querido; mas, con todo, vuélvete a mí, dice el Señor, que yo te recibiré (Jer 3, 1-2) (Tratado del amor de Dios 1: I, 951-2).

Larga ha sido la cita, pero merecía la pena. En ella se muestra el manejo ágil de la Escritura, su interpretación correcta y su aplicación al objeto espiritual que pretende, mostrar el amor que Dios nos tiene, a partir de las muestras de amor que en el Antiguo Testamento manifestó a Israel. Después pasa al Nuevo Testamento para describir el amor de Dios manifestado en la entrega por nosotros de su propio Hijo. Y sigue el mismo procedimiento, apoyándose ahora en textos del Nuevo Testamento (Jn y Pablo), interpretados también literalmente, derivando a continuación hacia una reflexión puramente teológica. En efecto, el amor de Dios manifestado en Cristo, se pone de manifiesto de manera concreta en las tres gracias que Cristo nos otorga por su encarnación: la divinidad unida a la humanidad; el ser cabeza espiritual de todos los hombres; la gracia infinita de la santificación (Tratado del amor de Dios 4: 954-6).

No siempre, por lo demás, es fácil saber si la explicación de un texto es literal o según otros procedimientos. Y con frecuencia mezcla unos y otros. Un ejemplo interesante lo encontramos, cuando explica cómo hemos de «olvidar nuestro pueblo», de acuerdo con los versos del salmo que le sirven de apoyo para su escrito. Interpretando aquí «nuestro pueblo» en el sentido negativo de «el mundo», va desgranando los nombres de "nuestro pueblo», del que hemos de salir. Son nombres bíblicos que designan el «mundo» en sentido de enemigo del hombre. Así, utilizando etimologías populares y aceptadas en su tiempo, interpreta Egipto como tiniebla o angustia; Babilonia, como confusión; los caldeos, Sodoma, Edón, con otros mil nombres, como representación de la maldad de este pueblo. Este es el pueblo del que Dios manda salir a Lot, del que Dios hace salir a Israel, del que, en primer lugar, salió Abraham. Y toda la reflexión se cierra con la cita de 2 Cor 6, 14-17, que él propone en su sentido inmediato y literal. (AF IV, 1-5: 505-7).

Finalmente, por recordar un caso más, veamos cómo nuestro autor interpreta un texto del Antiguo Testamento en referencia a una realidad espiritual sin contradecir su sentido literal, pero sin entrar en cuestiones lingüísticas o de pura literalidad histórica. Aunque haga referencia a posiciones tradicionales en su tiempo, como por ejemplo que la lengua hebrea era la lengua del paraíso y la que hablaban los seres humanos antes de Babel, san Juan de Ávila no entra en dis- 
cusiones sobre las lenguas, sino que interpreta el episodio de Babel de un modo más profundo y real, sin contradecir el significado profundo del texto:

\begin{abstract}
A las palabras que algunos hablan tan mal, que oírlos es oír sirenas que matan a sus oyentes, es bien que veamos a quién tenemos que oír. Para lo cual es de notar que Adán y Eva, cuando fueron criados, un solo lenguaje hablaban, y aquél duró en el mundo hasta que la soberbia de los hombres, que quisieron edificar la torre de la confusión (cf. Gén 11, 1-9), fue castigada, con que, en lugar de un lenguaje con que todos se entendía, sucediesen muchedumbres de lenguajes, con los cuales no se entendiesen unos a otros. En lo cual se nos da a entender que nuestros primeros padres, antes que se levantasen contra el que los crió, quebrantando su mandamiento con mala soberbia, un solo lenguaje espiritual hablaban en su ánima, el cual era una perfecta concordia que tenían uno con otro y cada uno en sí mismo, y con Dios, viviendo en el quieto y pacífico estado de la inocencia. Mas, como edificaron torre de soberbia ensalzándose contra el Señor de los cielos, fueron castigados, y nosotros con ellos, en que en lugar de un lenguaje y con que bien se entendían, sucedan otros muy malos e innumerables, que nos molestan con su fatiga y no nos entendemos con ellos, con su gran confusión y tiniebla ... que son lenguaje de mundo y carne y diablo (AF I, 1: 409-10; 2AF c. 1, 3: 540).
\end{abstract}

De esta manera, obviando discusiones complejas y complicadas en su momento, el intérprete ha retrotraído el episodio de la torre de Babel a su sentido más profundo y verdadero: no se trata tanto de buscar una razón que explique la diversidad de lenguas de los seres humanos (aunque algo de ello haya en el original bíblico), cuanto de referirlo a la incapacidad de entendernos que tenemos los humanos, a la dificultad para lograr un lenguaje espiritual que nos una y nos haga emprender conjuntamente obras de envergadura. $Y$ desde este punto de vista, la interpretación del Maestro Ávila es a la vez literal, moderna y profundamente verdadera.

\title{
Interpretación del Antiguo Testamento por el Nuevo
}

La lectura cristológica del Antiguo Testamento o, simplemente, su lectura cristiana, tan tradicional en los escritos de los Padres y teólogos que san Juan de Ávila conoce, aparece también con frecuencia en sus escritos. Veamos solamente un ejemplo, pero sumamente clásico y significativo. Se trata de la lectura cristológica del canto del siervo de Yahveh a partir de la frase de Pilato en los evangelios Ecce homo. Está hablando de la hermosura del alma, afeada por el pecado. Y recuerda que, por hermosear nuestra alma, el Hijo del Hombre esconde su belleza a los ojos del cuerpo. Inmediatamente recuerda el paso evangélico en que Pilato, ataviando a Jesús como rey falso y después de haberlo castigado, lo presenta ante el pueblo para suscitar la compasión de la gente, «aunque muy mal lo quisiesen». Inmediatamente se dirige a la interlocutora a quien dedica el escrito: 


\section{La Sagrada Escritura según San Juan de Ávila}

Pues decidme, si salió Cristo tal que bastaba a apagar el fuego de la malquerencia en los corazones de los que lo aborrecían, ¿cuánta razón es que su vista y salida encienda fuego en los corazones de quien lo conoce por Dios y le confiesa por Redemptor? Mucho tiempo antes que esto acaeciese vio el profeta Esaías este paso y, contemplando al Señor, dijo: No tiene lindeza ni hermosura. Mirámosle y no tenía vista; y deseámosle despreciado y el más abatido de los hombres, varón de dolores y que sabe de penas. Su gesto fue como escondido y despreciado y, por tanto, no le estimamos. Verdaderamente Él llevó nuestras enfermedades, y Él mismo sufrió nuestros dolores; y nosotros estimámosle como a leproso y herido de Dios y abajado (Is 53, 2-4).

Si estas palabras de Esaías quisiéredes mirar una por una, veréis cuán escondida estaba la hermosura de Cristo en el día que trabajó para hermosearnos. Dice la esposa en los Cantares, hablando con Cristo: Hermoso eres y lindo, amado mío (Cant 1,15$)$, y aquí dice Esaías que no tiene lindeza ni hermosura; y aquel en cuya cara se revén los ángeles, y la desean mirar (1 Pe 1,12), aquí dice que no tiene vista (AF VI, 24-5).

Sigue así, estableciendo contrastes entre lo que el Antiguo Testamento y el Nuevo dicen de Jesús, y lo que dice Isaías en el cántico del siervo. Y concluye la primera parte de esta exposición:

Pensaba Pilato, cuando ataviaba a este desposado con atavíos de muchos dolores, que para los ojos de aquel pueblo no más le ataviaba. Y atavíalo para ser visto de los ojos del mundo universo, sirviendo en esto, aunque él no lo sabía, a lo que Dios tanto había prometido, diciendo: Verá todo hombre la salud de Dios (Lc 3, 6). Esta salud Jesucristo es, al cual dijo el Padre: en poco tengo que despiertes a servirme los tribus de Jacob, y que me conviertas las heces de Israel, yo te di en luz de las gentes, para que seas salud mía hasta lo postrero de la tierra (Is 49, 6) (AF VI, 27: 525-6; cf. 2AF c. 110: 770-3).

Este modo de proceder, en que texto del Antiguo Testamento y del Nuevo se interpretan mutuamente no es ciertamente original de san Juan de Ávila, sino tradicional en la Iglesia desde sus orígenes, como puede verse ya en los escritos neotestamentarios. Él conoce bien el procedimiento y lo usa con libertad y maestría, especialmente porque conoce los textos de ambos testamentos casi de memoria, lo que le facilita el acudir enseguida a textos paralelos o complementarios, interpretando el Antigo Testamento con los ojos del discípulo de Cristo, que sabe ya ver en las páginas antiguas las huellas de Cristo y de su obra.

Con menos fuerza que el ejemplo anterior, recojamos sin embargo para terminar este apartado, una interpretación en la que conjuga la ilustración de un texto del Antigo Testamento mediante otro del Nuevo, utilizando en este caso claramente la alegoría. Me refiero a la Plática 2 para clérigos, que nuestro editor subtitula El sacerdote debe ser santo. El tema de la plática se desarrolla a partir del comentario a Sal 118, 66, que reproduce en latín sin traducción, como siempre que se dirige a clérigos: Bonitatem, et disciplinam, et scientiam doce me. 
Para tratar de lo que conviene a la dignidad del altísimo oficio sacerdotal que tenemos, ... me pareció traer aquí en medio las palabras del profeta David, que en sí mesmo nos enseñan y mueven de lo que conviene saber y tener ... Las palabras son Bonitatem, et disciplinam, et scientiam doce me, que parecen ser una cosa con los tres panes que el Señor dice que hemos de pedir a nuestro vecino para poner delante de nuestro amigo que viene de camino cansado (cf. Lc 11, 5-6).

Y porque David, aunque algún tiempo pecó, otro lloró, y le fue muy más amargo el lloro que sabroso el pecado, tuvo interior hambre de la virtud y gracia del Señor, y pídele con todas sus entrañas que le dé pan de bondad, y pan de disciplina y pan de ciencia (Plática 2, El sacerdote debe ser santo 1.3: 797-8).

Uno no sabe en este caso, si se trata verdaderamente de la interpretación de un texto del Antiguo Testamento por otro del Nuevo o, simplemente, de un recurso retórico, para hablar de tres realidades que configuran, tal como las explica el predicador, al sacerdote santo. En cualquier caso, se trata de una muestra interesante del uso y manejo tan natural de la interpretación de un texto veterotestamentario a partir de otro del Nuevo. O, quizás mejor, de la lectura cristiana de un texto del Antiguo Testamento, para quien es capaz de comprender la Biblia entera con los ojos del Maestro Jesús.

\section{Interpretación espiritual alegórica}

Si resulta difícil determinar qué se entiende en cada ocasión por sentido literal bíblico, lo es más aún el establecer qué se entiende por sentido espiritual. San Juan de Ávila es heredero de la doctrina medieval de los cuatro sentidos: el literal, que se refiere a los hechos; y el espiritual, a su vez repartido en tres: el sentido alegórico, que ayuda a fortalecer la fe; el sentido moral, que indica el modo de actuar; y el sentido anagógico, que nos hace entrever las realidades escatológicas. Sin embargo, no usa esta distribución de manera didáctica y expresa. Todo sentido espiritual se manifiesta en él por medio de la alegoría y la tipología. Detengámonos un momento en el uso que hace el santo de la alegoría, que podemos describir, a grandes rasgos, como una metáfora continuada, a partir de la cual se descubre un sentido espiritual más alto en cada detalle del texto.

Empecemos por un bello pasaje donde se conjugan la interpretación del Antiguo Testamento por el Nuevo y la interpretación alegórica. Está hablando del don de la castidad, que Dios da a algunos en el espíritu y en la parte sensitiva:

Dificultosa cosa de haber parecerá ésta; mas, en fin, es obra y dádiva de Dios, concedida por Jesucristo, su único Hijo, en el tiempo del cual estaba profetizado que habian de comer juntos lobo y cordero, oso y león (Is 11, 6); porque las afecciones irracionales de la parte sensitiva, que como fieros animales quieren tragar y maltratar la ánima, son pacificadas por el don de Jesucristo y, dejada su guerra, viven en paz, como dice en Job: Las bestias de la tierra te serán pacíficas, y con las bestias de la región tendrás amistad (Job 5, 23) (AF I, 25: 419). 


\section{La Sagrada Escritura según San Juan de Ávila}

El texto de Isaías, cuyo sentido mesiánico es tradicional en la Iglesia desde siempre, se usa aquí en sentido alegórico: las pasiones son el lobo, el oso y el león, que devoran al alma; Cristo, el cordero, las pacifica, de manera que vivan en paz en el interior del hombre la parte sensible y la parte espiritual.

Un ejemplo de alegoría clásica, a partir de Cant 2, 15, verso de libro leído alegóricamente en el mundo judío y en la Iglesia cristiana desde sus mismos orígenes, podemos encontrarlo un poco más adelante. El Maestro Ávila explica cómo podemos vencer las asechanzas del demonio, que batalla contra el progreso espiritual del alma:

Y porque el vencimiento de esta batalla más se hace por arte de contentarnos con lo que viene y de tener confianza, mientras más el demonio nos la quiere quitar, que por vía de fuerza ... por eso dice el esposo a la esposa en los Cantares: Cazadnos las pequeñuelas zorras, que destruyen las viñas, porque nuestra viña ha florecido (Cant 2, 15). La viña de Cristo nuestra ánima es, plantada con su mano y regada con su sangre. Esta florece cuando, pasado el tiempo en que fue estéril y seca, comienza nueva vida y fructifica al que la plantó. Mas, porque a los tales principios suelen acechar estas y otras tentaciones del astuto demonio, y les suelen dañar con hacerles desmayar, trayéndoles pensamientos tan feos estando ella ternecica y en flor, por eso nos amonesta el esposo florido, que pues nuestra ánima, viña suya, ha florecido, que tengamos manera para cercar estas importunas tentaciones. En decir cazar da a entender que ha de ser por maña y no por fuerza. $Y$ en decir que son zorras, da a entender que son tentaciones solapadas ... En decir pequeñas, da a entender que para quien las conoce no son grandes, porque el solo conocerlas es vencerlas ... Y en decir que destruyen las viñas, da a entender cuánto daño hacen en los hombres que no las conocen (AF I, 51: 428).

El ejemplo de alegoría es perfecto y nada tiene que envidiar a ejercicios semejantes de Orígenes, de san Agustín o de san Bernardo. Y como él podemos encontrar muchos en ambas ediciones de su libro de espiritualidad. Alguno, como la interpretación de la guirnalda de Salomón en Cant, es bien querido por el Maestro Ávila, que lo usa en distintos momentos. Se refiere a él con ocasión de explicar el conocimiento de Jesucristo por parte del alma que emprende la aventura espiritual. Y para reforzar cuanto viene diciendo, hace un alto en el camino, exponiendo un lugar de los Cantares:

Por el trabajo de nuestro conocimiento y de la imitación de Jesucristo crucificado, hemos de pasar y esperar la gloria eterna de la resurrección.

Y esto mismo nos es amonestado en los Cantares, que dicen así: Salid y mirad, hijas de Sión, al rey Salomón con la guirnalda con que le coronó su madre en el día del desposorio de él, y en el día de la alegría del corazón de él (Cant 3, 11). En ninguna parte de la Escriptura Santa se lee que el rey Salomón fuese coronado con guirnalda o corona de mano de su madre, Bersabé, en el día del desposorio de él; y por eso según la historia no conviene al Salomón pecador. Por fuerza, pues la Escriptura no puede faltar, lo hemos de entender de otro Salomón verda- 
dero, el cual es Cristo, y con mucha razón, porque Salomón quiere decir pacífico; el cual nombre le fue puesto porque no trajo guerras en su tiempo, como las trajo su padre David (...).

Pues, si bien os acordáis, esposa de Cristo, de lo que es razón que nunca os olvidéis, la madre de este Salomón verdadero, que fue y es la bendita Virgen María, hallaréis haberlo coronado con guirnalda hermosa, dándole carne sin ningún pecado en el día de la encarnación, que fue día de ayuntamiento y desposorio del Verbo divino con aquella santa humanidad, y del Verbo hecho hombre con su Iglesia, que somos nosotros, y de aquel sagrado vientre salió Cristo como esposo que sale del tálamo. Y comenzó a correr su carrera como fuerte gigante (cf. Sal 18,6), tomando a pecho la obra de nuestra redempción, que fue la más dificultosa que ha habido (AF II, 60-61: 468-9).

El procedimiento es el habitual. Interpretando el Cantar como epitalamio para las bodas del rey Salomón, sentencia habitual entre los comentaristas del tiempo, encuentra que el hecho de la guirnalda no tiene respaldo «en la historia»; por tanto el sentido literal encierra un misterio, puesto que la Escritura es certísima y no puede faltar. Y esto es la justificación para llevar a cabo una atrevida interpretación alegórica, aunque no tan atrevida si tenemos en cuenta la tradicional interpretación alegórica del Cantar, como expresión lírica y a la vez misteriosa de los desposorios y amores entre Cristo, el esposo, y la Iglesia, su esposa ${ }^{19}$.

En fin, podríamos poner muchísimos ejemplos. Así, el verso de Jer 14, 18: «Si salgo al campo, veo muertos a espada; si entro en la ciudad, veo muertos y desperecidos con hambre». Aquí, los del campo son los que han salido de la ciudad, que es la Iglesia, y han muerto con la espada de la incredulidad; «los segundos son muchos de los que en la ciudad de la Iglesia tienen sana fe, pero están miserablemente muertos de hambre, porque no comen manjar de la obediencia de los mandamientos de Dios y de su Iglesia» (2AF c. 49, 2: 641-2).

Sin embargo, los que cumplen los mandamientos, los que «inclinan su oreja, obedeciendo con fe a Dios y a su Iglesia», son premiados con muy grandes mercedes, quedando el ánima satisfecha, hermoseada con fe y obras, «a semejanza de la hermosa Rebeca, a la cual fueron dados de parte de Isaac zarcillos para las orejas y ajorcas para las manos» (cf. Gén 24, 22; 2AF c. 49, 5: 642-3). Se trata, ciertamente, de un procedimiento abundantísimo en esta obra, donde a veces se enlazan interpretaciones alegóricas a lo largo de un capítulo entero, como sucede en 2AF c. 98: 748-51, donde alegóricamente se hace exégesis espiritual de la salida de Abraham (Gén 12, 1), de la Babilonia del Apocalipsis (Ap 18, 1-2), de la muerte de Cristo fuera de la ciudad (Heb 13, 12-13), de la muerte de Absalón (1 Sam 18), del traslado del arca de la alianza (1 Sam 6,

19. El mismo tema y la misma interpretación en 2AF c. 68-9: 681-5; Tratado del amor de Dios 8: I, 966-7, aunque en este caso varía la interpretación: «No hallo yo, Señor, una guirnalda, sino la que hizo tu madre la sinagoga el viernes de la cruz; no de rosas ni de flores, sino de espinas, para meter la cabeza». 


\section{La Sagrada Escritura según San Juan de Ávila}

10-12), del sacrificio de Isaac (Gén 22), de la figura de Melquisedec (a partir de Heb 7,3 ). Todo para explicar lo que significa la expresión Olvida a tu pueblo, es decir, para animar en su escrito a dejar el mundo y seguir el camino de los mandamientos de Cristo, el Señor.

\section{Interpretación tipológica}

Diferente de la pura alegoría es la interpretación tipológica, cuyo uso, muy frecuente en los padres de la Iglesia, tiene raíces bíblicas y ha pasado en gran parte a nuestros textos litúrgicos. En este caso, una persona, institución o cosa del Antiguo Testamento se percibe como sombra, figura, anticipo borroso de la realidad que aparece en todo su esplendor en el Nuevo Testamento.

Un ejemplo clásico, porque es usado por todos los padres de la Iglesia y por la liturgia, es el paso del mar Rojo (Éx 14). También el Maestro Ávila usa en este caso la tipología, aunque de un modo algo distinto al tradicional, que ve en el paso del mar Rojo un símbolo del bautismo. Para él se trata de la figura del aprieto en que nuestros pecados nos ponen y de la ayuda de Dios en este trance:

Todo lo cual es figura de aquel aprieto en que nuestros pecados nos ponen, representándosenos como enemigos muy fuertes, que nos quieren matar y tragar; mas la divina palabra, llena de toda buena esperanza, nos esfuerza diciendo que no desesperemos ni tornemos atrás a los vicios de Egipto, mas que, siguiendo el propósito bueno con que comenzamos el camino de Dios, estemos en pie confortados con su socorro, para que veamos sus maravillas; las cuales son que en la mar de su misericordia y en la sangre bermeja de Jesucristo su Hijo son ahogados nuestros pecados; y también el demonio, que caballero en ellos venía, para que ni él ni ellos nos puedan dañar (2AF c. 21, 6: 583).

Otro de los temas clásicos en este tiempo es la interpretación tipológica, y con amplias dosis de alegoría, de los vestidos del Sumo sacerdote a partir de Éx $28^{20}$. El mismo título del capítulo 109 de la segunda edición donde trata el asunto es bien revelador: «Que la sacra humanidad de Cristo fue figurada en la ropa del sumo sacerdote, y en el velo que Dios mandó hacer a Moisén...». Espiguemos alguna de las interpretaciones del Maestro Ávila:

La ropa que el sumo pontífice de la Ley se vestía había de ser de grana teñida dos veces, porque la santa humanidad de Cristo, que es su vestidura, se había de teñir en sangre por amor de Dios y del prójimo derramada.

20. Un poco después del Maestro Ávila, Benito Arias Montano escribe unas breves y eruditas páginas con el título Aaron, siue, Sanctorum vestimentorum ornamentorumque summa descriptio:ad sacri apparatus instructionem, Amberes, Plantin 1572, explicando los términos técnicos de este capítulo; y el canónigo abulense Diego del Castillo y Artiga escribirá más tarde un amplio tratado en latín, De ornatu et vestibus Aaronis, Lyon 1654; Amberes 1681, interpretando Éx 28 literal, tipológica y alegóricamente, para construir una especie de guía de vida espiritual para sacerdotes y cristianos. 
Y esta carne puesta en la cruz es el velo que Dios mandó hacer a Moisén, de jacinto y carmesí y grana dos veces teñida, de blanca y retejida holanda, hecho con labores de aguja, y tejido con hermosas diferencias (cf. Éx 28, 33). Porque esta santa humanidad es teñida con sangre, como el carmesí; es abrasada con fuego, significado en la grana, según hemos dicho; es blanca, como la holanda, con castidad e inocencia; y es retejida, porque no fue muelle, ni relajada, mas apretada debajo de toda disciplina virtuosa, y de muchos trabajos. Y está bien significada en el jacinto, que tiene color de cielo, porque es formada por obra sobrenatural del Espíritu Santo, y por eso se llama celestial; con otras muchas lindezas y virtudes que tiene, formadas por el saber muy subtil de la sabiduría de Dios. Y este velo manda que se cuelgue en cuatro columnas que lo sustenten, que quiere decir que en cuatro brazos de cruz fue puesto Cristo; y cuatro evangelios le ponen y predican manifiesto delante del mundo (2AF c. 109, 1: 769).

Como puede observarse perfectamente, el Maestro Ávila usa por una parte el sentido tipológico (las vestiduras del sumo sacerdote son figura, tipo de la humanidad de Cristo), y por otra explicita este sentido mediante un uso abundante de la alegoría, desentrañando uno por uno el significado de todas y cada una de las precisiones que Moisés dio para elaborar la túnica o velo sacerdotal.

\section{Otros modos de interpretación}

Según he dicho, san Juan de Ávila no sigue al interpretar la Biblia una clasificación sistemática de modos de interpretar. En cada momento echa mano del que le parece más conveniente y útil. Por eso no podemos reducir a un esquema perfectamente organizado los modos y maneras y métodos de interpretación de la Biblia que el Maestro usa. Los principales ya han quedado descritos, con algún ejemplo de muestra. Pero hay otras maneras de leer e interpretar la Biblia en sus escritos. Así, en algún caso el modo de leer e interpretar el evangelio parece estar condicionado, al menos en parte, por la liturgia y quizá por la religiosidad popular, como puede entreverse en el modo y manera como distribuye la meditación de la pasión de Cristo a lo largo de la última semana del Señor, que coincide en parte, y seguramente no por casualidad, con las celebraciones de la semana santa litúrgica en su tiempo: el lunes, oración en el huerto, prendimiento y encierro en casa de Anás y Caifás; el martes, acusaciones ante diversos tribunales y flagelación; el miércoles, el ecce homo, tema al que él dedicará las bellas meditaciones de los cuatro últimos capítulos en la segunda edición del Audi filia; el jueves, el lavatorio de los pies a los discípulos y la institución de la eucaristía; el viernes, la crucifixión y muerte; el sábado, la lanzada en el costado y el cuerpo exánime en brazos de María, su madre; el domingo, la resurrección y la gloria. Es casi el programa de una completa semana santa. Es verdad que en la liturgia lunes, martes y miércoles no están conectados con hechos concretos de Jesús; y que en su meditación el Maestro Ávila está le- 


\section{La Sagrada Escritura según San Juan de Ávila}

yendo el relato de la pasión de Juan 18-20. Pero no puede seguirlo literalmente, porque en él no se habla de la eucaristía, misterio al que alude el jueves con una referencia a Lc 22, 14-20, indicio claro de que, junto al texto bíblico, la organización litúrgica de la semana santa, en este caso el jueves santo, tiene su importancia. Es probable también, que una de las prácticas devocionales propias de esta semana, dedicando el sábado a contemplar a la Virgen dolorosa y en soledad, haya influido en el tema propuesto para la meditación en este día. Escritura, liturgia y devoción popular se aúnan en esta bella propuesta de meditación de la pasión del Señor. Por lo demás, esta página deja transparentar asimismo cómo el peso de la semana santa estaba en la pasión y muerte de Jesús y los dolores de María, no en la resurrección, que ni siquiera se propone explicar: «Del domingo no hablo, porque ya sabéis que es diputado al pensamiento de la resurrección y a la gloria que en el cielo poseen los que allá están, y en esto habéis de ocupar el día» (cf. AF II, 47: 460).

Tampoco es ajeno al modo de leer la Sagrada Escritura de nuestro autor un procedimiento menos técnico y usado con relativa frecuencia en todo tiempo. Me refiero al sentido acomodaticio o pura acomodación de un texto bíblico al objeto de que se habla, sin mayor fundamento que parecidos externos o la simple voluntad del expositor. Bien es verdad que en este uso de la Escritura es más bien parco, y se combina frecuentemente con el de otros sentidos. De hecho, en el Audi filia es difícil encontrar ejemplos puros de uso acomodaticio de la Biblia. Quizá uno de los más claros sea la lectura que hace de un par de textos bíblicos para explicar las dificultades a que se enfrenta el alma, cuando decide dejar la vida cómoda y emprender la senda de la perfección. Cuando tal ocurre, afirma el santo, vienen las grandes dificultades y los enemigos de todo tipo,

y le ponen en tal aprieto que, al primer paso que se levanta de la tierra y pone el pie en la primera de las quince gradas para subir a la perfección, es constreñido a decir: Como fuese atribulado, llamé al Señor y oyóme; Señor, libra mi ánima de los labios malos y lengua engañosa (Sal 119, 1-2). Labios malos son los que abiertamente impiden el bien, y lengua engañosa la que solapadamente quiere engañar. $Y$ algunas veces se ofrecen, o lo parece, tan grandes impedimentos para salir con lo comenzado, que son semejables a aquellos grandes gigantes que decían los hijos de Israel: Comparados nosotros a ellos, somos como unas pequeñas langostas. Y parecen los muros de la ciudad que hemos de combatir, llegar con su alteza a los cielos, y que la tierra que alli hay traga a sus moradores (Núm 13, 29.33.34) (2AF c. 23: 586).

Puede discutirse si el verso del salmo 119 es oportuno o no para describir la situación; pero la referencia al episodio de los gigantes es ciertamente una pura acomodación, puesta más para ilustrar plásticamente una situación espiritual, que como pasaje que tenga relación concreta con aquello de que se habla.

En algunas de las pláticas también usa, siempre sin demasiado abundamiento, este sentido acomodaticio. Por ejemplo, en la plática sacerdotal 2, El sacer- 
dote debe ser santo, que ya conocemos, intenta explicar la sentencia de Jesús, ¿Qué aprovecha al hombre que gane todo el mundo si pierde a su alma? (Mt 16, 26) con algunos casos del Antiguo Testamento, que son pura acomodación:

Eso nos quiso decir aquel sabio luchador y patriarca Jacob en los grandes sudores y trabajos que pasó para alcanzar a Raquel (Gén 29, 16-30). Y, después, viniéndole su hermano al encuentro y temiendo no le matase su gente, puso en la frontera su mujer y hijos menos amados, y par de sí a Raquel y al suyo (Gén 33, 2), con intento que, si peligro hubiese, alcanzase a lo que menos valía y quedase guardado lo que más. Josef deja la capa en las manos de la mala mujer por escapar la vida (Gén 39, 12); y Susana se ve en aprieto de pecar o perder la vida del cuerpo antes que ofender a Dios, y libróla Dios de un mal y del otro (Dan 13) (Plática 2, El sacerdote debe ser santo 3: I, 799).

Es claro que nada tiene que ver la sentencia de Jesús con la historia de Jacob y la de José, aunque sí pueda relacionarse con la de Susana. Ejemplo, por tanto, de un uso puramente acomodaticio, no para probar nada importante, sino puramente para ilustrar lo que viene diciendo, que es como usa este sentido.

Lo mismo puede decir de otro pasaje, esta vez del evangelio según san Juan, tal como se usa en una plática a las clarisas de Montilla:

Scitis quid fecerim vobis? (Jn 13,12), dijo el Señor a san Pedro y a los otros apóstoles después de les haber lavado los pies, y aun quizá besado; y lo mesmo os podemos decir agora, señoras, y os puede decir vuestro querido esposo Jesucristo: Scitis quid fecerim vobis? ¿Entendéis las mercedes que el Señor os ha hecho en apartaros del mundo y escogeros por esposas suyas? ¿Sabéislo, Señoras? ¿Conocéis lo que con vosotras ha hecho? ¿Tenéislo bien entendido? Que antes que fuésedes nacidas ni engendradas, y mucho antes, ¿qué digo «mucho»?, infinito, antes que el mundo se hiciese, os tenía ya Dios escriptas en su pecho a todas estas que aquí estáis para esposas suyas (Plática 15, Os escogió por esposas suyas 2: I, 881-2).

En este caso se trata de una evidente acomodación, utilizando una frase de la Escritura totalmente fuera de contexto y con un significado que nada tiene que ver con el suyo original. Pero ya he dicho que no es demasiado frecuente este uso en las obras estudiadas. Sin embargo, lo es más el de recurrir al inmenso caudal de la Escritura en busca de ejemplos con que ilustrar la enseñanza que va proponiendo. Es ésta también una práctica antigua y tradicional, que ya proponía san Agustín en su tratado De doctrina christiana dedicado a los predicadores ${ }^{21}$. En las dos ediciones del Audi filia se encuentran muchos casos en

21. Cf. por ejemplo De doctrina christiana IV, XII, 27, citando el De oratore de Cicerón, Madrid, BAC 1957, p. 295; sobre el uso de ejemplos en la predicación del siglo de oro, cf. J. ARAGÜÉs AldAZ, «Predicación divina, palabra y tópica ejemplar en los Siglos de Oro: Magis movent exempla quam verba», Salina X (1996) 55-68; M. ${ }^{a}$ L. LÓPEZ GRIGERA, La Retórica en la España del Siglo de Oro, Salamanca, Universidad de Salamanca 1989. 


\section{La Sagrada Escritura según San Juan de Ávila}

que se confirma o se apoya la enseñanza con ejemplos bíblicos ${ }^{22}$. Uno, que puede servir de modelo, lo encontramos en el relato de la enfermedad del rey Ezequías, ejemplo vivo, dice el autor, de cómo el Señor, a pesar del castigo justo que merecen nuestros pecados, nos oye con gran misericordia. Expone ampliamente, con estilo narrativo propio, toda la historia de la enfermedad del rey, su dolor y pena, su plegaria a Dios y la intervención de Isaías (2 Re 20, 1-11; Is 38). Toda esta página tiene la perfecta estructura del ejemplo: exposición de la doctrina, narración detallada y colorida del ejemplo, conclusiones morales y espirituales para la vida del lector. Veamos un extracto:

Leemos que en tiempos pasados concedió Dios una maravillosa victoria de sus enemigos al rey Ezequías ( $2 \mathrm{Re} 19$ ), el cual no hizo al Señor que le dio la vitoria aquellas gracias y cantares que era razón; por lo cual le hizo Dios enfermar, y tan gravemente que ningún remedio por naturaleza tenía. Y porque, con falsa esperanza de vivir, no se olvidase de poner cobro a su ánima, fue a él el profeta Esaías y díjole por mandado de Dios: Esto dice el Señor: Ordena tu casa, porque sábete que morirás y no vivirás (Is 38,1$)$. Con las cuales palabras atemorizado, el rey Ezequías vuelve su cara a la pared, y lloró con gran lloro, pidiendo al Señor misericordia. Consideraba cuán justamente merecía la muerte, pues no fue agradecido al que le había dado la vida, y miraba la sentencia de Dios contra él dada, que decía: No vivirás. No hallaba otro superior que aquel que la dio, para pedir que se revocase. Y, aunque le hubiera, no tuviera buen pleito, pues al desagradecido justamente se quita lo que misericordiosamente se le había dado. Viose en la mitad de sus días (Is 38, 10-20) y acabarse en él la generación real de David, porque moría sin hijos, y allende de todo esto, era combatido de todos los pecados de su vida pasados. Cayó en temor de los que más suelen penar a la hora postrera. $Y$ con estas cosas estaba su corazón quebrantado con dolor, y turbado así como mar, y adondequiera que miraba hallaba muchas causas de temor y tristeza; mas entre tantos males halló el buen remedio, y fue pedir medicina al que le había llagado, seguridad a quien le amedrentó, convertirse por arrepentimiento y esperanza al mismo de quien por ensoberbecerse huyó. Al mismo juez pide que le sea abogado, y halla camino cómo apelar de Dios no para otro más alto, mas apela del justo para el misericordioso. Y las razones que alega son acusarse, y la retórica son sollozos y lágrimas. Y puede tanto con estas armas en la audiencia de la misericordia que, antes que el profeta Esaías, pregonero de la sentencia de muerte, saliese de la mitad de la sala del rey, le dijo el Señor: Toma, e di al rey Ezequías, capitán de mi pueblo: Oí tu corazón y vi tus lágrimas; yo te concedo salud y te añado otros quince años de vida, y libra esta ciudad de tus enemigos (Is 38, 5-6). Señor, ¿qué es aquesto? ¿Tan presto metes tu espada en la vaina y tornas la ira en misericordia? (...) Todo lo disimulas con el amor que nos tienes, y a todo te haces sordo y ciego, por estar atento a hacernos mercedes (...) Tú, pues, pecador, quienquiera que seas, que estás amenazado por aquella sentencia de Dios que dice: El ánima que pecare aquella morirá (Ez 18, 20), no desmayes debajo

22. Véase, por ejemplo, 2AF c. 23, 2-3: 586-7, donde se usa la Escritura como abundante caudal de ejemplos. 
de la carga de tus grandes pecados y del incomparable peso de la ira de Dios, mas cobra ánimo en la misericordia de aquel que no quiere la muerte del pecador, mas que se convierta y viva (Ez 33, 11). Y humíllate llorando a aquel que despreciaste pecando, y recibe el perdón de quien tanta gana tiene de dártela, y aun de hacerte mercedes mayores que antes, como hizo a este rey, al cual levantó sano del cuerpo y sano del ánima. Como él da gracias diciendo: Tú, Señor, libraste mi ánima porque no se perdiese, y arrojaste mis pecados tras tus espaldas (Is 38, 17) (AF III, 37-39: 493-5).

Los ejemplos tomados de la Biblia no son casuales en los escritos y la predicación de san Juan de Ávila, como puede verse en la plática 3, A los padres de la Compañía de Jesús, que es una especie de tratadito de oración. En sus recomendaciones para predicar dice que, fundamentando todo en la Escritura, el sacerdote ha de enseñar al pueblo, que tiene un Dios que ayuda:

Y hase de enseñar este artículo, y fundar en la Escriptura las condiciones de nuestro Señor y sus entrañas, y que tiene más gana de dar vida, que nosotros le pedimos» (Plática 2: Tres grados en los que cursan oración 2: I, 813).

Y más adelante, apoyándose ahora en la vida de San Bernardo, escrita por Guillermo de Saint-Thierry, cuenta un ejemplo de la vida de este santo y, a continuación, mezclando castellano con latines, como es su costumbre cuando se dirige a clérigos, invita a usar ejemplos de la Biblia, para ayudar a comprender lo que se predica, como hizo el mismo Jesús, a quien presenta como predicador con ejemplos:

El tener a Dios en esta posesión y opinión es grande honra suya; muévese mucho a dar. Hase de formar este afecto en los corazones exemplis Scripturis, ut ex illo: Quis ex vobis habens amicum?, et caetera quae sub eodem capite sunt (cf. Lc 11, 3). Y aconsejaba el Señor in exemplo de muliere cum iudice (cf. Lc 18, 1-8), que seamos inoportunos; $y$ todos los lugares donde el Señor dice esto se deben mucho meditar, y el servicio y contento que el Señor recibe en que le pidan (Plática 3: Tres grados en los que cursan oración 4: I, 814).

No es el caso de poner más textos. El uso de la Escritura es tan connatural a san Juan de Ávila, quizá porque, como dicen sus contemporáneos, se la sabía prácticamente de memoria, que son numerosas y abundantes las páginas en las que ya no sabemos si las palabras que él usa son suyas o son pura sentencia bíblica. Este «hablar Biblia» es tan habitual en él, que prácticamente forma parte de su estilo de escribir. Pero, lo más interesante es que no usa de cualquier manera la Escritura, sino que siempre hace de ella un uso respetuoso y adecuado, acorde con lo que el texto significa, según los distintos procedimientos que acabo de exponer. Estamos, pues, ante un pastor, que conoce la fuerza de la palabra de Dios y sabe cómo hacerla presente mediante la Sagrada Escritura. Lo primero, es muestra de su grande fe, gracia recibida de Dios. 


\section{La Sagrada Escritura según San Juan de Ávila}

Lo segundo, es ejemplo de concordancia entre la fe y el conocimiento racional, conseguido con la ayuda de Dios y mediante serio estudio humano. Una buena combinación para acercarse el predicador o director espiritual al siempre fecundo libro de la Escritura divina.

\section{LA LECTURA DE LA BIBLIA POR EL PUEBLO CRISTIANO}

Tratándose de alguien que conoce y estima la palabra de Dios contenida en la Escritura de la manera como hasta aquí hemos podido apreciar, nada de particular tiene que aconseje la lectura de la Biblia a quienes dirige y predica. En el caso de los clérigos, no había problema, puesto que podían leer la versión latina de la Vulgata. Pero las cosas eran más complicadas para las religiosas y los laicos, especialmente después del índice de libros prohibidos del inquisidor general Fernando de Valdés en 1559, en el que se prohíben todas las versiones en lengua vulgar, incluso los extractos que de ellas pudiera haber en libros de piedad y espiritualidad ${ }^{23}$. Es éste uno de los campos en los que más se nota la revisión que el autor hizo en la segunda edición de su obra. Ya conocemos algunos de los pasajes en que el Maestro Ávila invita a leer la Escritura en la primera edición del Audi filia. Recordemos el primero y más clásico, que es suprimido en la segunda edición, como se ha notado más atrás:

inclinad vuestra oreja, quiero decir, vuestra razón, y no tengáis temor de ser engañada. Inclinadla a la palabra de Dios, que está dicha en toda la Sagrada Escriptura, y, si no la entendierdes, y os pareciere que va contra vuestra razón, no penséis que erró el Espíritu Santo que la dijo; mas sujetadle vuestro entendimiento, y creed que por la grandeza de ella vos no la podéis alcanzar. Y mirad que manda Dios por el profeta Esaías, que nuestro recurso sea a su santa Escriptura; ... Porque ... tener conocimiento de Dios y de lo que cumple a nuestra salud, no se alcanza sino por la sabiduría de la palabra de Dios. ... Y aunque a toda la Escriptura de Dios hayáis de inclinar vuestra oreja con muy gran reverencia, mas inclinalda con muy mayor y particular devoción y humildad a las benditas palabras del Verbo de Dios hecho carne ... Sed estudiosa de leer y oír con atención y con deseo de aprovechar estas palabras de Jesucristo. E sin duda hallaréis en ellas una excelente eficacia que obre en vuestra ánima, la cual no la hallaréis en todas las otras, que desde el principio del mundo Dios ha hablado ni ha de hablar hasta el fin de él (AF III, 2-3: 475-6).

La lectura de la Escritura es necesaria, según san Juan de Ávila, porque nos pone en contacto directo con la palabra de Dios, haciendo posible nuestro co-

23. Sobre las prohibiciones de leer la Biblia en el medievo y en el siglo de oro, cf. S. FERNÁNDEZ LÓPEZ, Lectura y prohibición de la Biblia en lengua vulgar. Defensores y detractores, León, Universidad de León 2003; más general, J.M. SÁNCHEZ CARO, La aventura de leer la Biblia en España, Salamanca, Universidad Pontificia de Salamanca 2000. 
nocimiento de Dios y, por tanto, nuestra salvación. Esta lectura ha de hacerse con profunda reverencia, incluso aceptando que no todo puede comprenderse: es preciso a veces sujetar la razón, que parece encontrar contradicciones y errores en la Escritura; en realidad no es el Espíritu Santo el que se equivoca, sino que la grandeza de esta palabra contenida en la Escritura va más allá de lo que podemos alcanzar con nuestra pequeña inteligencia. Especialmente importantes son las palabras de los evangelios, como palabras que son del Señor Jesús. Aquí hay que extremar la devoción y la humildad a la hora de acogerlas, sin olvidar poner toda la atención en ellas, leerlas con frecuencia y abrirnos a su eficacia, que es eficacia «excelente» más que la de cualquier otro medio, para la perfección en la vida espiritual y para nuestra salvación. Ahora bien, esta lectura no puede hacerse en solitario, como si cada cristiano fuese una isla y tuviese plena capacidad para entender lo que habla la Escritura. Leer la Escritura ha de ir acompañado de acoger y aceptar las enseñanzas de la Iglesia, en la que habita el mismo Espíritu que hizo nacer la Sagrada Escritura:

Item, inclinad vuestra oreja a la determinación y enseñanza de la Iglesia católica, cuya cabeza en la tierra es el Pontífice romano. Y tened por cierto, como san Hierónimo dice, que cualquiera persona que fuera de esta obediencia y creencia comiere el cordero de Dios, profano es. Y quienquiera que fuere hallado fuera de esta Iglesia, necesariamente ha de perecer, como los que no entraron en el arca de Noé fueron ahogados en el diluvio. Y contra la Iglesia no os mueva revelación ni sentimiento de espíritu, ni otra cosa mayor o menor, aunque viniese ángel del cielo a lo decir (Gál 1, 8), porque, como dice san Pablo, esta Iglesia es columna y firmamento de la verdad (1 Tim 3, 15), y mora en ella el Espíritu Santo, que ni engaña ni puede ser engañado (AF III, 4: 476-7).

Esta es la doctrina de la primera edición de su Audi filia. Una doctrina equilibrada, en la que el cristiano se debe alimentar de la palabra de Dios, pero en el ámbito de la Iglesia, que es quien sirve como punto de referencia definitivo, tal como insiste en el siguiente párrafo de este apartado, donde hace clara referencia a las doctrinas reformadas sobre la lectura de la sola Scriptura, sin atender a cuanto enseña la Iglesia (AF III, 5: 477-8).

Pero, como he dicho, las cosas no estaban para equilibrios. La radical prohibición de leer la Escritura en lengua vulgar, incluso la prohibición a los laicos de tener una Biblia no declarada, hizo que por este tipo de afirmaciones y otras semejantes, la primera edición acabase en el índice de libros prohibidos de $1559^{24}$. Era lógico que, en la revisión que lleva a cabo el Maestro Ávila de su obra, se viesen afectadas también varias de las páginas dedicadas a la Sagrada Escritura. Ya he hecho alusión a alguna de ellas. En el caso de los consejos

24. Sobre las vicisitudes de las dos ediciones del Audi filia, cf. el capítulo que le dedican los editores en SAN JUAN DE ÁvILA, Obras completas. Nueva edición crítica I, 169-193. 


\section{La Sagrada Escritura según San Juan de Ávila}

de leer la Escritura, algunos de ellos en parte se suprimen, en parte se modifican, si bien permanece lo sustancial. El final del capítulo es indicativo también del nuevo clima:

Y mirad no caigáis en curiosidad de querer saber más de lo que habéis menester para vos, o para la gente que tenéis a cargo; porque lo otro debéislo dejar para los que tienen cargo de enseñar al pueblo de Dios, como amonesta san Pablo, que nuestro saber sea con templanza (Rom 12, 3) (2AF c. 45, 6: 634).

Al comenzar a tratar de la consideración de nuestro Señor Jesucristo y de los misterios de su vida y de su muerte, recuerda que no basta para la vida espiritual el conocimiento de sí mismo, que por ser en general conocimiento de pecados y defectos puede desanimar, sino que se precisa el conocimiento sobre todo de Jesucristo, «especialmente pensando cómo padeció y murió por nosotros», lo que produce gozo y paz (2AF c. 68, 1: 680). Para ello da los siguientes consejos:

Y así por esto, como porque ningún libro hay tan eficaz para enseñar al hombre todo género de virtud, ni cuánto debe ser el pecado aborrecido y la virtud amada, como la pasión del Hijo de Dios; y también porque es extremo de desagradecimiento poner en olvido un tan inmenso beneficio de amor, como fue padecer Cristo por nos, conviene, después del ejercicio de vuestro conocimiento, ocuparos en el conocimiento de Jesucristo nuestro Señor (2AF c. 68, 2: 680).

Nótese, sin embargo, que nunca dice que se lea el Nuevo Testamento o el evangelio, probablemente debido a que era peligroso y estaba prohibido hacerlo sin permiso. Por eso, la palabra «libro» parece que debe interpretarse aquí metafóricamente y no del evangelio o de otro libro cualquiera sobre la pasión, libros que existían y se usaban. De hecho, un poco más adelante, cuando quiere señalar libros concretos, da incluso los títulos, aunque nunca recomienda la lectura de la Biblia... porque no era entonces posible. Así, en el capítulo 74 habla de leer «aquel mismo paso de la pasión que queréis pensar en algún libro que trate de la pasión». Es evidente que no se trata de los evangelios. Y por si quedaba alguna duda, especifica los libros que aconseja:

Y los libros que para pensar en la pasión pueden aprovechar, entre otros, son las Meditaciones de san Augustín, en latín, y las del padre fray Luis de Granada, en romance, y el Cartujano, que escribe sobre todos los evangelios (2AF c. 74, 1: 694) ${ }^{25}$.

25. San Agustín, Meditationum liber unus, 6-7; ML 40, 901 sg.; «Meditaciones» 6-7, en Obras completas de San Agustín. XLI: Escritos atribuidos, Madrid, BAC 2002; LUIS DE GRANADA, Libro de oración y meditación, Salamanca 1554; edición moderna, Libro de oración, Madrid, BAC 1999; L. DE SAJONIA, Vita Christi, versión de fray Ambrosio Montesino, Alcalá de Henares. Estanislao Polono 1502; versión moderna, La vida de Cristo: fielmente recogida del Evangelio y de los santos padres y doctores de la Iglesia, Madrid, Universidad Pontificia Comillas; Roma, Institutum Historicum Societatis lesu 2010. 
Se trata de libros clásicos de espiritualidad, todos ellos de absoluta garantía y muy leídos en el siglo XVI y posteriormente. Pero no son la Sagrada Escritura. En este momento, una mujer, laica o religiosa, no puede ya leer la Escritura en directo. Santa Teresa experimentó esta misma dificultad, que le arrebató incluso algunos de sus queridos libros de espiritualidad ${ }^{26}$. San Juan de Ávila no lo dice explícitamente, pero estas páginas son prueba de la misma situación.

\section{Predicar la palabra de Dios}

No es el Audi filia un escrito en el que hable el Maestro Ávila de la predicación, pues no va dirigido inmediatamente a los sacerdotes, que es a quienes habla de lo que significa predicar. Pero el tema es tan importante para este gran predicador y maestro, que no quisiera cerrar este somero repaso a alguna de las cuestiones fundamentales sobre la Sagrada Escritura sin dejar al menos constancia de su preocupación. Basta con echar una ojeada a la magnífica edición última de sus sermones, para percatarnos de que su predicación se mueve en el $95 \%$ de los casos acerca de textos bíblicos, principalmente en contexto litúrgico. Todo corroborado por el índice bíblico que cierra este volumen, donde son más de 3500 las citas bíblicas registradas ${ }^{27}$. Por eso, permítaseme un par de referencias sobre un asunto que ha sido ya ampliamente tratado por otros estudiosos ${ }^{28}$, espigadas en su Tratado sobre el sacerdocio y en alguna de sus pláticas a clérigos.

Interés especial tiene el Tratado. En su última parte habla precisamente de los sacerdotes predicadores, aunque por desgracia nos ha llegado incompleto. Pero cuanto dice es de sumo interés. Comienza en directo hablando de los «predicadores de la palabra de Dios»:

El oficio de los predicadores de la palabra de Dios es comparable a muchas cosas temporales, para que por ellas, como por rastro, vengamos en conocimiento de la alteza de este ministerio (Tratado sobre el sacerdocio 45: I, 944).

Y es que el predicador o lo es de la palabra de Dios, o no es propiamente predicador. De aquí, la bella y profunda lección que sigue sobre lo que es y hace la palabra de Dios en labios del buen predicador:

La Palabra del Señor, en boca de sus predicadores, riega la sequedad de las ánimas como pluvia del cielo venida (cf. Is 55, 10-11); y, embriagadas con dulce amor del Señor, les hace dar frutos de buenas obras. Y por experiencia se ve, que el

26. "Cuando se quitaron muchos libros de romance, que no se leyesen, yo sentí mucho, porque algunos me daba recreación leerlos, y yo no podía ya por dejarlos en latín», Vida 26, 4.

27. Cf. San Juan de Ávila. Obras completas. Nueva edición crítica III: Sermones. Edición, introducción y notas de L. Sala Balust - F. Hernández Martínez, Madrid, BAC 2002.

28. Cf. T. Herrero del Collado, Pastoral Bíblica del Maestro Juan de Ávila, Granada 1961; y L. Sala Balust en San Juan de Ávila. Obras completas. Edición crítica I, 245-58. 


\section{La Sagrada Escritura según San Juan de Ávila}

pueblo donde hay predicación de la palabra de Dios se diferencia de aquel donde no la hay como tierra llovida y fértil a la seca, que, en lugar de fruto, dé abrojos y espinas (cf. Mt 13, 18-23; Lc 8, 11-15). Mas, porque la tierra, aunque llovida, ha menester juntamente con su humedad ser ayudada del calor del sol, son también (los predicadores) comparados al mismo sol, porque con el calor y fuego de la palabra de Dios producen en las ánimas fruto provechos a quien lo hace, y sazonado y sabroso al Señor; y, con alumbrar el entendimiento, dan conocimiento de Dios y enseñan el camino del cielo, alumbrando de los tropiezos que en él se pueden ofrecer (Tratado sobre el sacerdocio 45: I, 945).

La fuerza de la palabra de Dios se pone de manifiesto en este párrafo, que es casi una glosa al texto del Segundo Isaías al que alude y a la explicación alegórica de la parábola del sembrador en los evangelios. La palabra de Dios predicada es Iluvia benéfica, que fertiliza la vida espiritual; es sol vital, que lleva las plantas nacidas de la tierra a su maduración espiritual; produce frutos, iluminando la inteligencia para dar a conocer a Dios y ayudar a descubrir el camino de la salvación, superando las dificultades para ser cristiano en esta vida. Tal es la esencia de la predicación, que se apoya como en su germen y semilla vital en la fuerza iluminadora y salvadora de la palabra de Dios.

Y no olvida el Maestro Ávila, que la Palabra de Dios por excelencia es el Verbo encarnado, «Palabra que del cielo descendió a este mundo» (Tratado sobre el sacerdocio 46: I, 945). Él es la verdadera luz que alumbró la tierra, el verdadero sol que le dio el calor de la vida. Y precisamente, lo que hizo la Palabra de Dios encarnada, eso es lo que puede hacer la palabra de Dios predicada:

Mas todos estos bienes que la Palabra de Dios increada obró en los cuerpos de los hombres y los que ganó, mediante su pasión, para las ánimas, los obra y efectúa mediante su palabra que acá dejó. Con ésta alumbra nuestras ignorancias, enciende nuestra tibieza, mortifica nuestras pasiones y, lo que más es, resucita las ánimas muertas, que es mayor obra que criar cielos y tierra. Con esta palabra hiere el Señor y da salud, mortifica y da vida, mete a los infiernos y saca (de) allí, humilla y ensalza ... Y no sólo le libra de la muerte, mas dale mantenimiento de vida, porque su palabra mantenimiento del ánima es; y agua con que se lave, fuego con que se caliente, arma para pelear, cama para reposar, lucerna para no errar.. (Tratado sobre el sacerdocio 47: I, 945).

Bello alegato de la eficacia de la palabra de Dios predicada en la Iglesia, donde resuenan tantas imágenes bíblicas, dedicadas a las palabras de profetas y apóstoles, palabras de fuego y de vida, de salvación y de denuncia y condena, de erradicación de vicios e injusticias, de implantación y crecimiento de la Iglesia. Por desgracia, aquí se interrumpe bruscamente el Tratado. Para completar, siquiera someramente, su pensamiento sobre el papel y la importancia de la palabra de Dios se requiere revisar alguna de sus pláticas, que parecen estar fundadas e inspiradas precisamente en él. 
Recordemos brevemente la plática 3, dirigida a los padres de la Compañía de Jesús, que ya hemos puesto de relieve. En ella, como hemos visto, recomienda a los sacerdotes, que deben fundar en la Escritura su predicación del Dios bueno que ayuda a los hombres, y que expliquen todo esto con ejemplos de la Escritura (Plática 3: Tres grados en los que cursan oración 2: I, 813-4. Recuérdese también lo que ya se ha dicho antes acerca de la necesaria preparación bíblica del sacerdote, a partir de la plática 10: Seréis mis amigos si guardáis mis mandamientos (I, 867-8).

Por otra parte, cuando se repasan los memoriales del santo dirigidos al Concilio de Trento o al de Toledo, la cuestión de la predicación adecuada de la palabra de Dios por clérigos competentes y consecuentes con lo que predican es casi una obsesión. Así, en su Memorial primero para el Concilio de Trento, escrito en 1551, al hablar de «la reformación del estado eclesiástico», hace un claro retrato de la situación de la predicación de la palabra de Dios, tal como él la ve en su tiempo en España:

Dice este santo concilio: Haya en las iglesias lección de santa Escriptura ${ }^{28}$. Bien mandado está por cierto; mas, ya que haya quien la lea porque se lo paguen, pregunto: ¿quién lo oirá? Ya se ha probado a hacer esto en nuestros tiempos en algunas catedrales, y lo que de ello se ha sacado es que, de tanta muchedumbre de clérigos como en ellas hay, ninguno, o uno o dos, no de los más principales, van a oír; y si algunos legos vienen también, se cansan; y así se deja el negocio, o se hace sin fructo por falta de oyentes...

Dice también, y muy bien, este santo concilio que declaren los curas a sus parroquianos el Evangelio. Pregunto: ¿Qué es de los curas que lo sepan entender y tengan modo para declararlo y vida para ser oídos? Los más no lo entienden. Y hay algunos de tal vida, de los pocos que lo entienden, y conocida por tal, que no osarán hacer esto; o, si lo hacen, se seguirá más escarnio de ellos o de lo que predican, que daño de no predicar» (Memorial primero al Concilio de Trento 3: II, 486).

En resumen, el mandato de Trento de dar lecciones de Sagrada Escritura y de explicar el evangelio chocaba en España con el poco interés de la gente por este tipo de predicación, y la falta de preparación del clero. La consecuencia que de ello se deriva es la necesidad de preparar buenos predicadores de la palabra de Dios, porque el oficio de predicadores de la palabra de Dios

está muy olvidado del estado eclesiástico, y no sin gran daño para la cristiandad (...) Y si alguno dijere que basta haber curas medianamente enseñados que declaren al pueblo el Evangelio, digo que no es medicina bastante para llagas tan afistoladas como las hay; mayormente que muy presto yerra el saber de los pocos sabios, si no son encaminados por otros mayores sabios. Y también son menester doctos predicadores para que discurran por los obispados, según se dirá; y han menester ser sabios para los diversos e intrincados casos que se les ofrecerán. Y

28. Cf. EB 65. 


\section{La Sagrada Escritura según San Juan de Ávila}

también es menester hombres doctos para que lean lección de Sagrada Escritura en las Iglesias, según este sagrado concilio ha mandado ${ }^{29}$. Y también son menester predicadores sabios para compañía del obispo; con los cuales acompañado y cercado, como capitán con caballeros, sea terrible contra los demonios (Memorial primero para el Concilio de Trento 14: II, 493).

Para ello, concluye el Maestro Ávila, debe haber centros específicos de formación tanto para confesores, como para predicadores de la palabra de Dios, «donde se eduquen los de mejores ingenios y les den la ciencia que en su vaso cabe, para salir muy doctos lectores y predicadores, a los cuales se les pueda encomendar sin miedo el tesoro y alteza de la palabra de Dios» (Ibid. 5: II, 494).

En el Memorial segundo al concilio de Trento, escrito diez años después, en 1561 , vuelve a insistir en los mismos temas. Son los obispos lo primeros que deben dar ejemplo y predicar personalmente el Evangelio:

Porque hay mucha gente que no sabe estimar el valor de las cosas por lo que son en sí mesmas, sino por lo que ve ser estimada de los mayores, quería Dios, y con mucha razón, que los prelados a quien él había honrado, lo honrasen a él con la gente del pueblo, enseñando con sus propias lenguas su santo Evangelio y andando con sus propios pies sus limpios caminos, autorizando con todas sus fuerzas la verdad de Dios y dando a entender con buenos ejemplos que la vía de la cruz y el estrecho camino que lleva a la vida, por áspero que parezca al mundo, es posible e imitable, y aun lleno de suavidad, a quien se esfuerza a caminar por él con el favor del Señor (Memorial segundo al Concilio de Trento 10: II, 531).

En cuanto a los clérigos predicadores, recuerda que no basta saber muchas sutilezas teológicas, como empeñarse con todo su estudio y toda su fuerza «en averiguar y enseñar cuál es pecado mortal o venial y cuál obra de precepto o de supererogación, y esto muy fríamente»; ni basta con predicar cuanto pide el evangelio, pero diciendo que no estamos obligados a esas perfecciones, sino que son únicamente consejos (Ibid. 12: II, 534). Hay que predicar la palabra de Dios y para ello es necesario conocer bien la Sagrada Escritura. Pero, vuelve a insistir, escasean los hombres doctos en Sagrada Escritura. Por lo que una segunda vez vuelve a proponer un centro para formarlos, esta vez como instituto anexo a las universidades:

$\mathrm{Y}$, porque esta facultad ${ }^{30}$ pide estudio por sí, cuidado, diligencia y diuturnidad de tiempo, desocupación de negocios, maestro docto, iguales con quien conferir, abstinencia y oración, pureza de afectos, para que así por medios humanos y también cristianos se pueda alcanzar el espíritu del cielo para bien la entender -pues omnis

29. Cf. EB 65.69.71.

30. La palabra «facultad» tiene aquí sentido académico, como facultad de gramática, de medicina, de teología, significando lo que hoy entendemos en el lenguaje universitario por «titulaciones»; lo que propone, por tanto, es una titulación específica de Sagrada Escritura. 


\begin{abstract}
Scriptura eo spiritu legenda quo est facta- sería cosa utilísima a la Iglesia dar orden para que en las universidades hubiese colegios diputados y dotados para que la dicha Sagrada Escriptura tuviese colegiales y discípulos que con estas dichas disposiciones la pudiesen estudiar; y con tener ejercicios de leer y predicar así entre los mismos colegiales como a gente de fuera, se hiciesen hábiles para hacer fructo en la Iglesia de Dios con el ejercicio y ministerio de su palabra. Con este medio habría lectores suficientes para leer la Sagrada Escriptura en las universidades, pues vemos por experiencia hallarse pocos de estos. Porque requiere esta lección otro diferente modo, y espíritu y pericia de la que pide la teología escolástica, en la cual solamente están ejercitados los más de los que leen la Sagrada Escriptura (Memorial segundo al Concilio de Trento 67: II, 591).
\end{abstract}

Esta es la propuesta del Maestro Ávila, hecha con visión larga de la realidad y que sólo mucho más tarde se materializará en la Iglesia con el Instituto Bíblico de Jerusalén, fundado por el padre Lagrange y el Pontificio Instituto Bíblico de Roma, fundado por san Pío X, uno a finales del siglo XIX, otro a comienzos del siglo XX. Una propuesta que él quiere insertar, con buen acierto, en el entramado universitario de la época, como una titulación específica, «una facultad» dice él, dentro de lo que eran los centros académicos del momento, los colegios mayores ${ }^{31}$. Una propuesta global, porque quienes estudiaren la Sagrada Escritura, deberían antes conocer la teología, pues «parece que se debía proveer que no oyesen la Sagrada Escriptura hasta que hobiesen oído la teología escolástica». Pero ésta sola no basta, porque:

Ya se ve por experiencia cómo los que toman oficio de predicar, habiendo solamente oído teología escolástica, lo hacen muy desaprovechadamente, de lo cual está la razón manifiesta, pues la ciencia que hace llorar y purificar los afectos para quien lee y la doctrina con que se ha de apacentar las ánimas provechosamente, en la Sagrada Escriptura y en concilios y en la lección de los santos está; y como de esto estén ayunos, no pueden dar provechoso pasto a las ovejas, antes algunas veces suelen contradecir a los que lo dan. Mándese que, antes que prediquen, hayan oído, después de la teología escolástica, tales y tales libros de la Escriptura divina y estudiándolos con diligencia, en lo cual sean examinados; si no fuese alguno que, sin haber oído, diese buena cuenta en el dicho examen (Memorial segundo al Concilio de Trento 69: II, 593).

Coherente hasta el final con sus principios, el Maestro Ávila es consecuente en sus propuestas, llenas de realismo y modernidad, teñidas también de la concepción que Erasmo tiene de la verdadera teología. No critica la escolástica tan dura e hirientemente como lo hace el humanista de los Países Bajos; pero tampoco se fía de una formación puramente escolástica. La verdadera teología, la

31. Cf. I. GomÁ CIVIT, «Un texto inédito del Beato Maestro Juan de Ávila sobre el estudio de la Sagrada Escritura», Estudios Bíblicos 1 (1943) 107-119; F. CERECEDA, «Dos proyectos de 'Instituto Bíblico' en España durante el siglo XVI», Razón y Fe 133 (1946) 275-90. 


\section{La Sagrada Escritura según San Juan de Ávila}

que llega al corazón, la que no solamente enseña sino que ayuda a la conversión, es la teología que nace de la Sagrada Escritura, de la que unas líneas antes ha dicho que es la teología de verdad, al defender que todo teólogo «que recibe el grado de teología sepa algo de lo que principalmente lo es», y sin lo cual uno no es verdadero teólogo (Ibid. 68: II, 592) ${ }^{32}$.

FINAL

No es necesario sacar conclusiones de este somero análisis acerca de las ideas y la imagen que san Juan de Ávila refleja en sus escritos. He intentado presentar los temas mayores, dejando hablar al santo predicador y teólogo, pero sobre todo al Maestro que sabe leer la Escritura con ojos de teólogo, con ojos de pastor, con ojos de Iglesia, con la certeza de que es palabra de Dios que hace viva el Espíritu en el ámbito de la Iglesia en que ella misma nació. Su pensamiento, al menos el que se refleja en los textos estudiados, es moderno, porque es tradicional. Siendo fidelísimo a Trento está a la vez muy cerca del Vaticano II. Es el milagro de la inteligencia guiada por la fe, de la libertad cristiana de pensar ahormada por el amor a la Iglesia en la que sabe que vive, en la que sabe que tiene sentido su teología y su predicación. Tomó lo mejor del humanismo erasmiano, sin dejarse llevar por la crítica general de instituciones venerables en la Iglesia de su tiempo. Sabía que la reforma verdadera de la Iglesia nace en el corazón de los cristianos, especialmente de los sacerdotes y obispos. Sabía, sobre todo, que el oficio del clérigo predicador es antes de nada hacer presente, viva y actual la palabra de Dios. Y que, para ello, es necesario seria preparación, profunda fe, oración constante, amor a la Iglesia y, sobre todo, comunión con Jesucristo, Palabra encarnada y dador del Espíritu que hace comprender el profundo misterio de la Escritura. Este es el retrato final que resulta de la reflexión aquí escrita. Inteligencia y corazón, apertura al Espíritu y obediencia a la Iglesia, conocimiento a fondo de la Escritura y contacto personal y amoroso con la Palabra encarnada, entrega de pastor y estudio de Maestro y Doctor: tales son las constantes decisivas y básicas que mueven a san Juan de Ávila en su continua lectura y estudio de la palabra de Dios escrita, de la Sagrada Escritura.

32. Recuérdense las palabras de Erasmo, después de criticar la vana teología escolástica, y compárense con el lenguaje del Maestro Ávila: «At precipuus theologorum scopus est sapienter enarrare divinas literas: de fide, non de frivolis quaestionibus rationem reddere; de pietate graviter atque efficaciter disserere; lachrymas excutere; ad coelestia inflammare animos. Ad haec iam inde a studiorum initio praeludat futurus theologus, potius quam in alienis literis consenescat»; Ratio seu methodus compendio perveniendi ad veram theologiam, Moguntiae, ex off. J. Schoeffer 1521, f. 17r. 